\title{
Tekmeria
}

Vol 14 (2018)

$(2017-2018)$

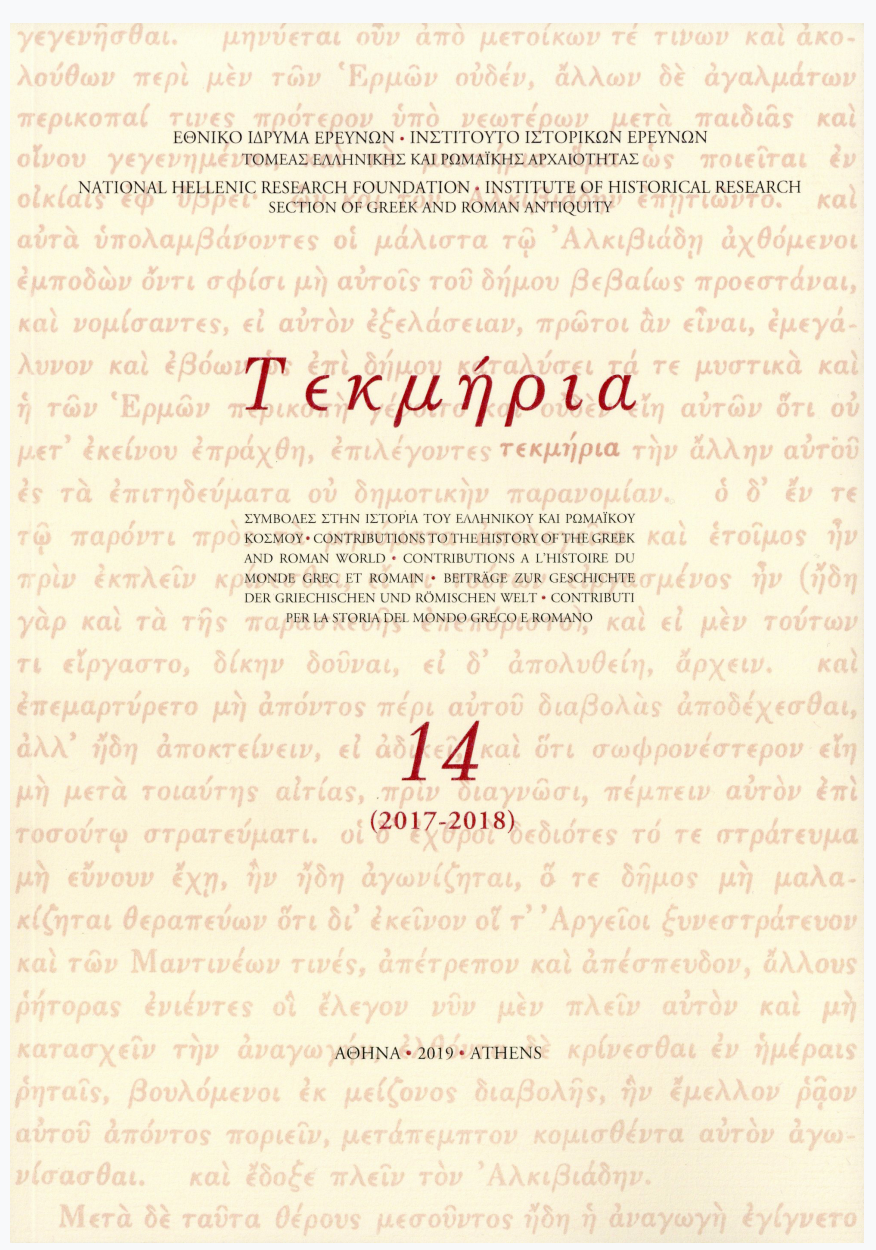

\section{Proskynēsis: From a Persian Court Protocol to a Greek Religious Practice}

\section{Takuji Abe}

doi: $10.12681 /$ tekmeria.14682

Copyright @ 2018, Takuji Abe

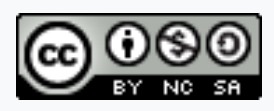

This work is licensed under a Creative Commons Attribution-NonCommercialShareAlike 4.0.

\section{To cite this article:}

Abe, T. (2018). Proskynēsis: From a Persian Court Protocol to a Greek Religious Practice. Tekmeria, 14, 1-45. https://doi.org/10.12681/tekmeria.14682 


\section{TAKUJI ABE}

\section{Proskynēsis: From a Persian Court Protocol to a Greek Religious Practice*}

\section{The proskynēsis problem}

It was in the last decade of the eighteenth century that the British established their first embassy in China, with the aim of opening new avenues for trade. At this time the Qing Dynasty was at its most prosperous, representing a dominant world power. Before being admitted to the court, in accordance with Chinese court ceremony, an incoming ambassador was expected to prostrate himself (to kowtow) in the presence of the ruling Qianlong Emperor. The incoming British ambassador George Macartney refused to do so, however, claiming that it was unnatural for him to pay greater homage to a foreign prince than he would bestow upon his own sovereign. He offered to kneel before the emperor instead, and to kiss his hand, as was customary when one was presented before the King of England at that time. This offer of compromise was most exceptionally agreed to, albeit with the omission of that British custom which would have him kiss the emperor's hand. Despite this initial diplomatic success, the original mission to obtain trade concessions was largely unsuccessful in the end (fig. 1). ${ }^{1}$ The episode promptly reminds one of a passage from Herodotus. ${ }^{2}$ In Book 7.136 he recounts an incident where Persian guards ordered two Spartan ambassadors to Susa to perform a Persian court ritual, but the Greeks refused to do so on the grounds that it was not their custom. One could

\footnotetext{
* An early version of the paper presented here was read as a lecture at the National Hellenic Research Foundation in Athens, in March of 2016. The first section was partly based on the paper read at the 68th AGM of the Classical Society of Japan, in June of 2017. This study is also financially supported by Kyoto Prefectural University's Research Grant for Younger Scholars.

1. Cranmer-Byng 2000, 119.

2. This is not only my interpretation. Powell's lexicon to Herodotus $(2004,323)$

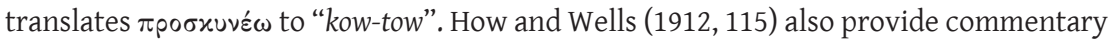
on 1.134 by writing that "The prostration of an inferior is familiar in the East (iii.86.2); it was as repulsive to the Greeks as the Chinese 'kowtow' to Doyle's 'Private of the Buffs'”.
} 
be allowed some degree of surprise upon learning of such similarity between events transpiring in ancient Persia and eighteenth century China. The Greek name for this act required in the presence of the Persian king is proskynessis. It is the main subject of this paper. ${ }^{3}$

Proskynesis is normally interpreted as the act of "falling down" and prostrating oneself. ${ }^{4}$ More specifically, proskynēsis was thought of as a mode of subjection performed before the Oriental despot in particular, as is clearly insinuated by Isocrates. ${ }^{5}$ This ardent fourth-century supporter of the Greek cause against Persia put an emphasis on Persian weakness and servility by saying:

"They [the Persians] keep their minds in a humble state and cringe in fear because they are subject to a single man's power; they present themselves for inspection at the door of the royal palace, prostrate themselves ( $\pi$ pox $\left.\alpha \lambda \iota \nu \delta \circ{ }^{\prime} \mu \varepsilon v o \iota\right),{ }^{6}$ practice a lowly attitude of mind, and make proskynesis before a mortal man

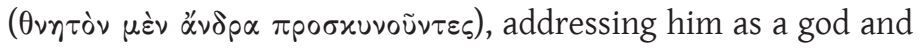
showing less respect for gods than for men" (Isoc. Paneg. 151).

The act of homage to Persian royalty as described by Isocrates may be reflected in iconography. A late Apulian vase known as the "Darius Vase", discovered in South Italy and dated to ca. 340-330 BC, carries a depiction of the court of Darius the Great (fig. 2a-b). ${ }^{7}$ The middle one of three registers depicts

3. Wiesehöfer $(2001,2003)$ gives a brief overview of the proskynessis problem.

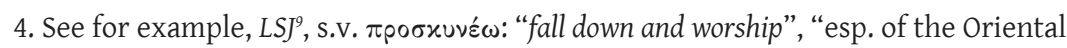
fashion of prostrating oneself before kings and superiors". In this paper I will not distin-

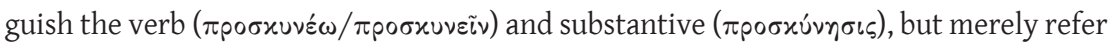
to proskynēsis or doing proskynēsis.

5. See also Eur. Or. 1507: "I fall down and do proskynēsis to you, my lord, according to the barbarian custom".

6. Прох $\alpha \lambda \iota v \delta \varepsilon \varepsilon_{0} \mu \alpha_{l}$ is a compound verb which is made up of the preposition pro-, followed by the verb kalindeomai (to roll about). This verb is used in Dem. 19.338 to describe Aeschines as having prostrated himself in front of Philip. See further Chantraine 1968-1980, S.v. $x \alpha \lambda \iota \nu \delta \varepsilon ́ o \mu \alpha \iota$.

7. This vase (volute-krater) is now displayed in the National Archaeological Museum of Naples (Naples 3253). The scene in the krater is interpreted as referring to the Persian Wars, or perhaps to the Ionian Revolt. Anti (1952) relates it to the Persai, a lost tragedy 
the Persian king Darius, enthroned and listening gravely to a messenger, who

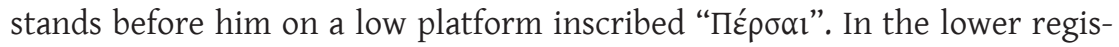
ter an exchequer counts and receives tributes, and next to him stand three men dressed in Persian attire, kneeling down and performing an act generally thought to be proskynēsis.

At first glance, both literary and iconographic evidence would seem to clarify what kind of act proskynessis represents. In actual fact, the matter remains unclear and unresolved. It is the striking differences between the evidence laid out above, and examples of the gesture collected from Persian iconographic records that stand in the way of our doing so. In the reliefs of the Treasury building and the One Hundred Columned Hall at Persepolis, ${ }^{8}$ a man standing in front of the enthroned king makes a light bow with his right hand lifted to his lips; acts of prostration are not depicted (fig. 3). This gesture was probably also applied as part of funeral ceremony; on the façades of the royal rock-cut tombs in Naqsh-i-Rustam and Persepolis, belonging to Darius and his successors, "mourners" carved on the right edge are depicted bringing their hands to their mouths (fig. 4).

The Persepolis motif of the royal audience was reproduced, and consequently diffused into the West. ${ }^{9}$ The Persians chose Dascylium as the location of one of their satrapal centres in Asia Minor. More than four hundred bullae were excavated from the southern sector of its mound, including twelve seal impressions featuring the king's audience (dated to the reign of a certain Artaxerxes - most likely the first), depicting a liege man, standing before the king with his right hand raised to his mouth. ${ }^{10}$ The Alexander sarcophagus, now one of the masterpieces of the Istanbul Archaeological Museums, is traditionally considered to be the funeral monument of Abdalonymus, a king of Sidon appointed by Alexander the Great. Among the reliefs decorating its sides, there is an audience scene, in which a Persian soldier is shown holding a shield that

of Phrynichus; see also Trendall, Cambitoglou 1982, 484-485; Schmidt 1982. For the work of the Darius Painter and his Circle, see Trendall 1989, 89-94.

8. The audience scenes on the two bas-reliefs of the Treasury building are almost identical mirror images of each other. They are proven to have originally been placed in the north and east stairway façades of the apadana building, but for an unknown reason they were later removed to the less accessible Treasury building: see Tilia 1972, 175-240.

9. For the diffusion and reception of the Persepolitan audience scene, see Allen 2005. 10. Kaptan 2002, i. 28-40; ii. 50-55. 
depicts on its concave side the image of a courtier making a light bow before his king. ${ }^{11}$

How may we resolve this obvious contradiction between Greek and Persian sources of literary and iconographic evidence? To that end, this paper will endeavour to elucidate the true nature of proskynēsis as part of Persian court protocol, ${ }^{12}$ and to show why the Greeks were so unwilling to perform this ceremonial act. Firstly, it will be argued that the term proskynēsis does not represent any single posture, but is used to refer to a range of different acts. Secondly, this paper will define the specific form of proskynēsis as it was normally performed at the Persian court, as a bow with one hand raised up to the mouth. In subsequent parts, this paper will discuss Greek ideas about the two modes of proskynēsis as part of Persian court protocol and Greek religious practice; more specifically, why the Greeks remained loath to accept

11. von Graeve 1970, 102-109, pls. 69-71.

12. Among the preceding studies on the pose of proskynesis, the commentary on Xenophon's Cyropaedia 4.4.13 by Holden $(1887,99)$ says, "'did obeisance', 'prostrated themselves' in the Oriental fashion, and kissing the ground." A short note by Scott (1922) argues that the original gesture of proskynesis was "simply the waving of a kiss", and prostration is "only a derived or attendant meaning" to it. Horst (1932) is the only monography focusing on the problem of proskynesis. Horst uniquely started his study from a contemporary interest inspired by the liturgical movement of German Protestant churches, and wanted to find roots of its discussion in the text of the New Testament. He points out the etymological meaning of proskynein as "blowing a kiss" but, at the same time, stresses a complexity of the word which includes multiple postures. Richards (1934) compares proskynessis to the Indian salaam, that is, a low bow with the palm of the right hand touching the forehead, rather than the Chinese kowtow, prostration with the head touching the ground. Hamilton $(1969,150-152)$ makes a comment with the performance of proskynesis before Alexander that as far as it was performed before the Persian king (so, in this case, Alexander), proskynēsis involved prostration. Hall (1989, 96-97) suggests that this Persian court protocol was called proskynessis and identified with the Greek religious gesture, since the Greek genuflected before the images of gods. Marinatos (2007), who discusses Minoan cultural affinities with the Near East, calls the pose of prostration shown in a Cretan ring impression proskynesis, and connects it with divine kingship. Most recently Matarese $(2013,2014)$ identifies proskynēsis primarily as "sending a kiss". 
the requirement of performing proskynessis in front of the Persian King, by explaining that among the Greeks it was a privilege reserved only for the divine entity.

\section{Proskynēsis between a bow and prostration}

Herodotus, our most valuable witness to Achaemenid history, discusses various practices of Persian culture in the first book of his Histories (131-140) and -albeit sometimes in vain- attempts to interpret them. In 134 he introduces us to the manner in which the Persians greet each other:

"There is a sign by which one may know whether or not two Persians who encounter on the street are equals. If they are, then instead of greeting to each other, they kiss each other on the mouth; if either of them is of a slightly lower rank, they kiss each other on the cheeks; and if one of them is very much inferior, he falls down and offers proskynēsis in front of the other person

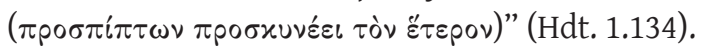

First of all, one should bear in mind the broad variety of connotations attached to the word proskynesis. The remarkable thing is that of the two classical Greek writers quoted thus far, Herodotus and Isocrates, both named prostration separately from proskynēsis, instead of choosing to mention the two practices side by side. ${ }^{13}$ Persians, they say, prostrate themselves and then perform proskynesis. A more discernible example of this is to be found in a chapter by Polybius:

"They [the Roman legates] began by reminding the assembly that when the Carthaginian envoys came to Tunis to see the Romans and were received by the council, not only did they salute

13. A similar expression is used also in Heliodorus' Aethiopica: "they prostrated

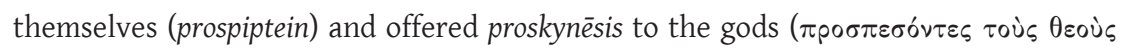
$\pi \rho \circ \sigma \varepsilon x u ́ v \eta \sigma \alpha \nu)$ " (10.6.2). Hesychius' lexicon explains $\pi \rho \circ \sigma x u v \varepsilon i ̃$ as $\pi \rho \circ \sigma \pi i \pi \tau \varepsilon$, however. See also schol. ad Aesch. Pers. 152b: “ $\pi \rho \circ \sigma \pi i \tau v \omega \cdot \pi \rho \circ \sigma x u v \tilde{\omega}$ ”. Strabo (15.3.20) paraphrases the passage of Hdt. 1.134, by saying "those of still lower rank merely make proskynēsis

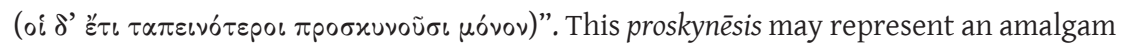
with the connotation of prospiptein, which Herodotus consciously distinguishes as separate in the original. 


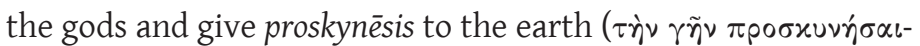
$\varepsilon v)$, as is the custom with other men, but also ( $\dot{\alpha} \lambda \lambda \dot{\alpha} x \alpha i)$ they abased themselves by falling prostrate on the ground ( $\pi \varepsilon \sigma \delta \sigma^{\prime} \tau \varepsilon \varsigma$ $\dot{\varepsilon} \pi \grave{\imath} \tau \dot{\eta} \nu \gamma \tilde{\eta} \nu \dot{\alpha} \gamma \varepsilon v \nu \tilde{\omega} \varsigma)$ and kissing the feet of the council members" (Polyb. 15.1.6-7).

This sentence, not least the conjunction "alla kai", suggests some possible interpretations. One explanation is that Polybius intended to emphasise the humble attitude of the Carthaginians by repeating similar verbs. An alternative interpretation is that it demonstrates the posture of proskynessis as clearly separate from that of prostration. The two acts could also be seen as having inherently different natures; proskynessis might be a religious act in deference to the gods and the earth, while falling prostrate on the ground was a secular act directed at the Roman council members. In any case, we are warned from instantly identifying proskynēsis with simple prostration. ${ }^{14}$

Although Polybius uses the word proskynēsis to refer to an action that came before prostration, we are unfortunately not in a position to know whether it was merely a small gesture or a more elaborate act. In order to decide on this matter, we are forced to rely on circumstantial information surrounding the situation in which proskynessis was performed. A battle narrative from Plutarch's Lives may provide a hint:

"Afraid that this sight [his horse was startled by the enemy shouts and suddenly wheeled about] might be taken as a bad omen and lead to confusion among the Romans, Marcellus quickly reined his horse round to the left and forced this animal to face the en-

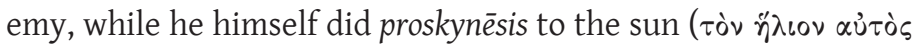
$\pi \rho \circ \sigma \varepsilon x \cup ́ v \eta \sigma \varepsilon v)$, implying as if it was not by chance but for this purpose that he had wheeled his horse; for it is the custom with the Romans to turn round in this way when they offer proskynesis

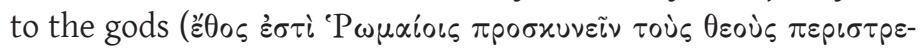
५orévous)" (Plut. Marc. 6.10-12).

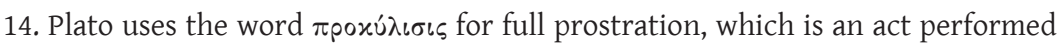

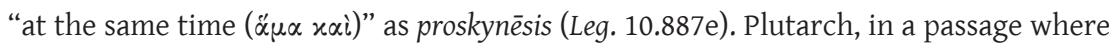
he lists superstitions that Greeks learned from barbarians, certainly also distinguishes

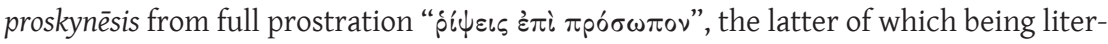
ally described as casting oneself down with face to the ground (De superst. 166a). 
Proskynēsis is referred to here as the sort of gesture that can be made on horseback. We may therefore reasonably speculate that this proskynēsis must have been a modest gesture capable of being performed in such a situation, as opposed to a gesture that would require some acrobatic feat, as would be the case for prostration or kneeling on horseback. Like Marcellus' proskynesis on horseback, Caracalla performed proskynessis while standing on a moving chariot (Dio Cass. 78.10.2). Mounted on said chariot, and holding a whip, the

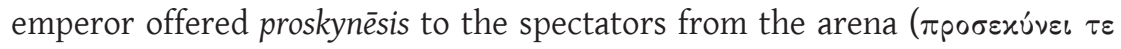
$\alpha \dot{u} \tau o \dot{\zeta} \chi_{\alpha}^{\prime} \tau \omega \theta \varepsilon \nu \tau \tilde{\eta} \mu \dot{\alpha} \sigma \tau \iota \gamma()$, for the purpose of requesting gold pieces in the manner of a performer from the lowest class. Here also, we can safely exclude prostration and kneeling; this proskynesis must be a small gesture or handsign, especially given the fact that Caracalla could have had only one hand free (his other hand would have been holding the whip and reins).

Among classical writers, it is Lucian who most clearly defines proskynessis as a gesture, although he is rather late. In an essay attributed to him, the Encomium of Demosthenes, ${ }^{15}$ a certain Archias had been charged by Antipater with the arrest of all exiles, Demosthenes being among them. Encountering him during his last moments in the temple of Poseidon at Calaureia, Archias observed Demosthenes raising his hand up to his mouth as he ended his life by ingesting poison. What is interesting here is Archias' mistaken belief; when Demosthenes put his hand on his mouth, Archias misunderstood that

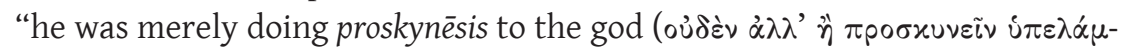
bavov)" (Lucian Demosth. 49). This passage seemingly affirms that the act of performing a kiss is a part of proskynesis, ${ }^{16}$ just as we observed in the Persian

15. There is a huge dispute about whether the Encomium of Demosthenes was a genuine product by Lucian or not, "based on the alleged inferiority of the Greek style and language employed in the piece and on the grounds of its inferior satirical qualities and general lack of inspiration" (Baldwin 1969, 54). For instance, M.D. Macleod (1967), the editor of Lucian's corpus of the Loeb Classical Library, assumes that it was written in imitation of the style of Lucian by a sophist who knew Plutarch's Life of Demosthenes, before the middle of the fourth century. Baldwin (1969), however, rebutted this general accepted assumption and argued that this encomium is truly written by Lucian.

16. Cf. Lucian Sacr. 12: "the poor man appeases the god by merely kissing his right

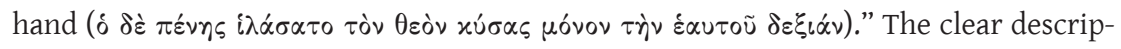
tion of this gesture is also encountered in Latin literature. In the Golden Ass of Apuleius, when the citizens and strangers saw a beautiful daughter of a certain king, "they, as 
iconographic instances from Persepolis. ${ }^{17}$ It has been suggested that the grand marshal in the Persepolis relief is not performing a kiss, but is instead preventing his breath from polluting the air made sacred by the two incense burners standing between the king and his subjects, an explanation that remains one of the possibilities. ${ }^{18}$ R.N. Frye alternatively proposes that "[t]he hand upraised before the mouth may be simply an expression of awe or surprise, as among the ancient Hebrews. A special significance is not necessarily implied". ${ }^{19}$ At any rate, the proskynēsis posture assumed by Demosthenes corresponds to its etymological interpretation. Proskynein (to do proskynesis) is a compound of the prefix pros- and the verb kynein: pros- means "toward, forward and in addition to", and kynein is "to kiss". ${ }^{20}$

astonished with admiration of her incomparable beauty, did no less worship and reverence her, bringing their right hands to their lips, with the forefingers laid against the thumb, as tokens, and with other divine adorations, as if she were Lady Venus indeed" (Met. 4.28). Pliny also explains that to raise the right hand to the lip in adoration was a Roman custom (HN 28.5.25). The Latin verb adorare was regularly used for the equivalent term of the Greek proskynein after the imperial period, probably because the word came to be associated with a hand-kissing gesture due to a mistaken etymology: see Marti 1936.

17. Although we do not know what its source was, the Lexicon of Hesychius (s.v.

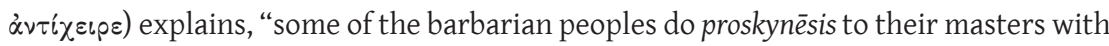

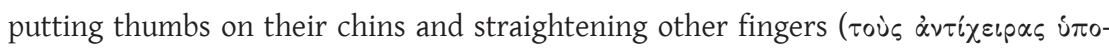

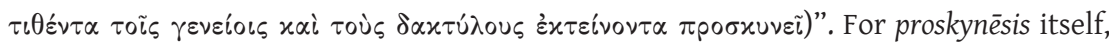
however, Hesychius gives a different definition: see above, n. 13.

18. Junge 1940, 16-17 n. 8. More recently, see Stoneman 2015, 71. A fragmentary stone relief from Dascylium, which is dated to the fifth century, also shows two male figures wearing headgear, probably in order to avoid their breath from reaching the fire in front of them; for the picture, see Moorey 1988, 47-48, pl. 45. Strabo (15.3.15) speaks of "Persian magi" of the Roman era wearing round their heads turbans of felt that reach down over their cheeks, far enough to cover their lips.

19. Frye 1972, 106 n. 1.

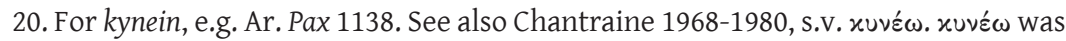
an uncommon verb, mainly used in poetry. In prose, $\varphi \iota \lambda \varepsilon \dot{\omega} \omega$ was preferred. Musti (2003) suggests the possibility that Poseidonius of Apameia provides an alternative etymolog-

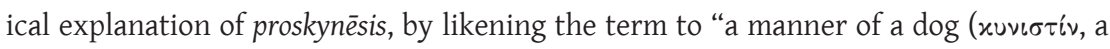


Now we shall go back to the passage of Herodotus 1.134 and examine the act of proskynessis it describes. Here Herodotus explains how the Persians greet each other during an encounter on the street: those of equal status or of a slightly different rank kiss each other, but those of a much inferior rank fall down and offer proskynessis before their superiors. The posture of this proskynēsis cannot be clearly deduced from its context, but it may refer here to "sending a kiss". ${ }^{21}$ That is to say, Herodotus introduces us to how the Persians change their way of kissing depending on the differences of their relative social status: if it is equal or at least not too dissimilar they may kiss each other directly (on the mouth or cheek), but if the difference in status is too great, they maintain distance and offer an indirect kiss (proskynēsis) from a lower position instead.

There are, however, some examples among our literary sources that confine our understanding of proskynessis to one representing a more grandiose action. According to Aristotle's analysis, the tamest and gentlest of all the wild animals is the elephant, "for there are many things that this animal both learns and understands: they are even taught to do proskynēsis before the king (ì $\pi \varepsilon i$ x $\alpha \grave{i}$

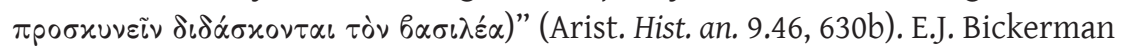
explains that the elephant is revering the king with its trunk raised. ${ }^{22}$ I prefer, on the contrary, to interpret this infinitive as "to kneel"; this proskynesis is something that had to be taught (as opposed to the raising of the trunk, which is part of an elephant's instinctive natural behaviour), and kneeling is the most basic posture -and therefore the first behaviour taught by a trainer- required for the purpose of riding an elephant. What is more, we have an additional example from classical literature that is similar, and even more clear-cut. When he invaded the territory of Armenians and Parthians, Trajan was sent gifts by satraps and princes from the region. "Among these gifts was included a horse

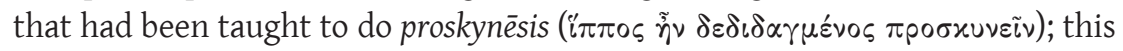
animal would kneel on its fore legs and place its head below the feet of whoever stood near" (Dio Cass. 68.18.2). This horse was so tamed and well-trained as to prostrate itself to its master.

Besides animals, people are also known to have performed a more elaborate form of proskynēsis. When Atossa, his beloved daughter, was covered

hapax)" (FGrH 87 F 5). Delatte (1951) interprets the prefix pros- as adding the nuances of "repetition" or "intension", and proskynēsis as "a kiss with fervour".

21. Musti 2003, 165.

22. Bickerman 1963, 247. 
with leprosy, Artaxerxes II "offered prayers to Hera on behalf of her, mak-

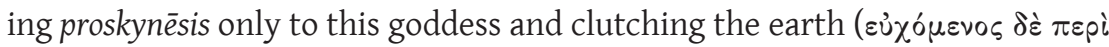

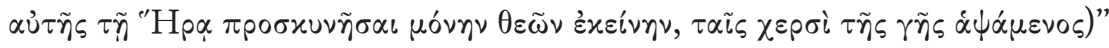
(Plut. Artax. 23.7). When someone clutches the earth, it seems more natural that he would bend his legs and knees on the ground, rather than bending his body with the legs straight; this proskynēsis must represent a kneeling or prostration. Proskynessis as a more substantial action is also referred to in the Aethiopica, an ancient Greek romance attributed to a certain Heliodorus. Although it was most likely written during late antiquity, the novel is set in the Early Achaemenid period and refers to proskynessis several times. In order to celebrate the Ethiopian army's victory over the Persians and the Egyptians, a man of such high stature as to be equal to those seated on raised thrones was led into the court and introduced to the Ethiopian king Hydaspes. When the man stepped out and performed his proskynesis before the king, "it seemed all but that he bent to kiss the king's knee" (Heliod. Aeth. 10.25.1). Upon imagining what this occurrence may have looked like, it would seem that the obeisance he performed must lie somewhere between a light bow and full prostration; a deep bow, or kneeling -not necessarily excluding genuflection- is likely.

We now seemingly find ourselves back where we started. What kind of gesture was proskynessis? From the etymological viewpoint, its original definition is expected to have been "to send a kiss forward". We are nevertheless not in a position to trace the development from this narrow, specific definition to a wider, more general usage, since our most evident example for a meaning, as would be derived from its etymology, can only be recognised (with the exception of Hesychius) ${ }^{23}$ in Lucian, a later and non-native Greek author. Among the available written sources, different gestures are attested in different ages. Herodotus is one of the first writers who used this word, ${ }^{24}$ and he himself already applied proskynēsis to more than just one posture. In the Egyptian logos,

23. See above, n. 17.

24. The earliest surviving use of the verb proskynein is encountered in the fragment of Hipponax of Ephesus, from the middle sixth century BC: "After waiting for the dawn of white-robed day by his side, you will offer proskynesis to the Hermes of the Phlyesians" (F 47, West). Aeschylus also uses the verb once in the Persians (499). The noun proskynesis starts to appear in the fourth century in the philosophical works of Plato (Leg. 10.887e) and Aristotle (Rhet. 1.5.9, 1361a36). 
our ethnographer describes the Egyptian manner of greeting, just as he did for the Persians in the preceding book:

"They [the Egyptians] have another custom which is known nowhere in Greece: instead of greeting each other when they meet on the streets, an Egyptian does proskynessis by lowering his

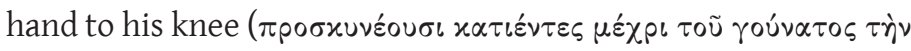
$\chi \varepsilon i \tilde{\rho} \alpha) "$ (Hdt. 2.80).

If a man brings his hand down to his knee he cannot kneel down, nor can he prostrate himself; the proskynesis in this case must be understood as a bow. A relief depicting a typical Egyptian bow has in fact been excavated at Amarna, providing us with a visual understanding of what Herodotus strove to explain in writing (fig. 5). The official in this fragment, bowing at the waist, lowers only his left hand -we should remember that Herodotus used a singular for the hand ( $\tau \dot{\eta} \nu \chi \varepsilon i \tilde{\rho} \alpha)$; this relief may constitute proof of the accuracy of Herodotus' observation, despite it having preceded the historian by 900 years. ${ }^{25}$

The discussion so far makes clear that the range of postures to which proskynēsis was applied is diverse even among ancient Greeks, and therefore we have to renounce the idea that proskynessis can be associated with any one single, specific gesture; we have to interpret this word in several different ways, depending on its context, with possibilities ranging between "sending a kiss forward", kneeling down, prostrating oneself, or just a bow. At the very least we must remove from our mind the presumption that proskynesis is automatically equal to prostration.

\section{Proskynesis in the presence of the Persian king}

In Greek literature proskynēsis is an act of homage to be performed before a Persian king, not least on the occasion of a new king's coronation. This inaugural obeisance is mentioned repeatedly by Greek authorities on the subject of Persian history. With regard to the moment when Cyrus the Great ascended to the throne, Xenophon describes: when the Persians looked at Cyrus clad in a splendid fashion on a chariot,

25. We also have the hieroglyphic sign of a man performing a bow and holding his hands forward (A16), signifying the ancient Egyptian word meaning "to bow down". See also Lloyd 1976, 341; Asheri, Lloyd, Corcella 2007, 295. 


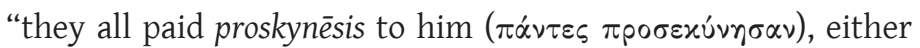
because some had been instructed to begin this, or because they were overwhelmed by his preparation and their thought that Cyrus' appearance was so great and beautiful. Nobody of the Persians had ever done proskynēsis to Cyrus before ( $\pi \rho \sigma^{\sigma} \sigma \theta \varepsilon v \delta \grave{\varepsilon}$

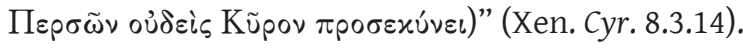

At this moment, Cyrus rose in status from a mere adorable prince to an inaccessible king, and so he accepted proskynēsis from his formerly "equal" companions; ${ }^{26}$ Callisthenes, our best-known anti-proskynēsis advocate, later spoke mockingly of Cyrus as being "the first of men to receive proskynēsis ( $\lambda \dot{\varepsilon}-$

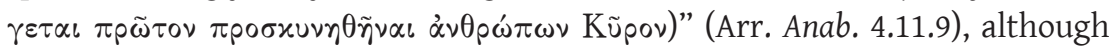
this statement is erroneous, as will be discussed later.

Herodotus narrates the procedure of installing a new king as discussed by six Persian nobles, Darius I being among them, after the slaying of false pretender Smerdis. They decided that the rider whose horse first neighs at sunrise should be granted the kingdom. Thanks to a trick on the part of his groom Oebares, Darius' horse whinnied first, and at that very moment, lightning and thunder emanated from a clear sky. Convinced that these phenomena marked the birth of a new king, "his companions jumped off their horses and per-

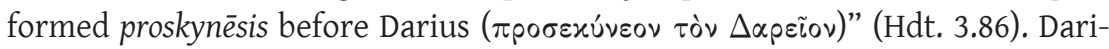
us' two sons, Xerxes and Ariamenes, are said by Plutarch to have been rivals for the kingship, even though in Herodotus' opinion Xerxes' succession to the throne was obviously secured (7.3). When Xerxes was declared king, Ariamenes approved of his kingship by "making proskynēsis [to his brother] immediately,

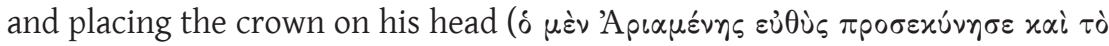

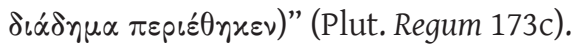

Take another instance: the plan of Cyrus the Younger to usurp the Persian throne was foiled. However, upon seeing his Greek mercenaries defeat the unit opposite them on the battlefield at Cunaxa, "he was pleased and was already

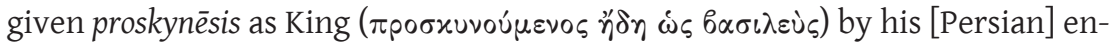
tourage" (Xen. An. 1.8.21). This battle was ultimately won by his elder brother, Artaxerxes II. After the hostilities concluded, this new king ordered his men to

26. Llewellyn-Jones (2015) points out the functioning of dress and a clothed body as articulator of the monarchy's power in the Achaemenid context. Here, Cyrus' new garment makes a demarcation between him and his subordinates. 
cut off the head from the body of his deceased brother, displaying it to those still wavering or ready to flee. They were surprised by his death, and consequently made proskynessis to Artaxerxes (Plut. Artax. 13.3). That is to say, during the battle of Cunaxa, Persians offered proskynessis to both Cyrus and Artaxerxes, depending on whoever was deemed the likely victor at that particular moment in battle. All the records quoted above treat the act of proskynesis itself as the quintessential acknowledgment of a new king's royalty. It remains unfortunate that the nature of this gesture or act cannot be ascertained from the context of these records. Was it a grandiose action, such as prostration or kneeling, or a more modest posture, such as a bow or sending a kiss?

When Alexander the Great inherited the Achaemenid imperial territories, ${ }^{27}$ he also marked this succession by adopting Persian court ceremony for his Greek and Macedonian subjects. Chares of Mytilene, Alexander's court

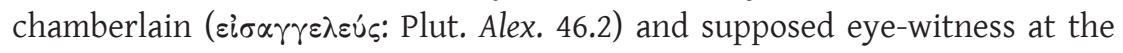
scene ${ }^{28}$ tells us what transpired on the first occasion when the practice of proskynēsis was carried out. ${ }^{29}$ His story is recorded by Arrian (Anab. 4.12.3-5) and Plutarch (Alex. 54) with some divergence in detail. ${ }^{30}$ The events, taking

27. Alexander's introduction of proskynēsis was accompanied with the adoption of other Iranian regalia, garments, customs and institutions. For his "Persian" or more widely, "Iranian" reforms at his court after 330, see Olbrycht 2014.

28. Chares was considered a second-rate historian, his accounts being flattering to the king and seemingly hostile to Callisthenes: see Badian 1981, 50-51. For a reappraisal study of Chares, see Spawforth 2007.

29. Alexander's attempt to introduce proskynessis among his Companions, specifically whether had the intention of being regarded as the divine monarch, is one of the most debated topics involving proskynessis; see further, Taylor 1927; Balsdon 1950; Badian 1981; Bosworth 1988b, 278-290; Badian 1996; Fredricksmeyer 2000; Matarese 2013. Bowden

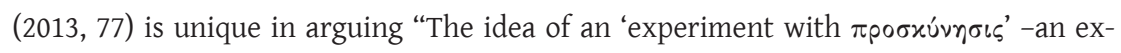
periment that failed and was not repeated- is an invention of the later tradition. It was inspired by distaste among writers of the Roman imperial period for what they took corrupting Persian practices to involve". Pace Bowden, Arrian, Plutarch, Curtius, and Justin (12.7.1) are in agreement with regard to this experiment. As for Diodorus, there is a long break in our text of his Book XVII, where events of 327 should have been described.

30. Arrian (4.12.2) does not reveal his source, but gives it as an anecdote (" $\alpha \dot{\alpha} \alpha \gamma \dot{\varepsilon} \gamma \rho \alpha$ -

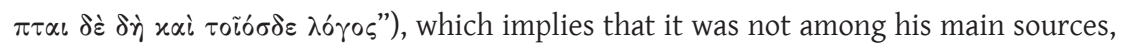


place at a symposium in Bactra in 327, are described as follows: Alexander sent round a wine phiale, first to those who agreed to his proposal of proskynēsis. In Arrian's account, "the first who drank up from the phiale then stood up, paid

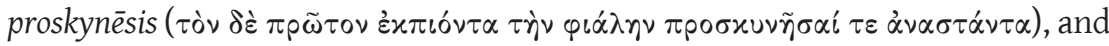
received a kiss from Alexander; so it went through all in turn". In Plutarch's Life, on the other hand, "he, on receiving the phiale, stood up so as to face the household shrine; next he drank, then gave proskynessis to Alexander, and

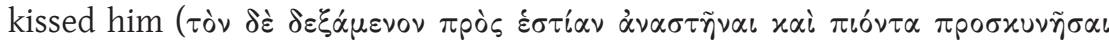

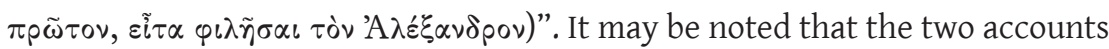
differ in their description of the proceedings. In Plutarch's version, attendees rise before drinking, and in Arrian's account there is no mention of attendees facing the household shrine; moreover, whereas Arrian describes Alexander bestowing his subjects with a kiss, Plutarch describes Alexander as receiving a kiss from his subjects instead. These contradictions notwithstanding, both historians are in agreement about what happened with the ardent anti-prosky$n \bar{e}$ sis advocate. Callisthenes came up to Alexander to kiss him, without doing proskynesis; Alexander, in conversation with Hephaestion, did not notice that Callisthenes omitted the procedure of proskynessis until one of his Companions, Demetrius son of Pythonax, ${ }^{31}$ told on him to Alexander.

We have to assume that the exact posture of proskynesis was known to Alexander, as his Persian attendants taught him, or possibly even demonstrated to him, how it should be performed. Oxyathres, the younger brother of Darius III, must have been the key figure in this, as according to Plutarch (Alex. 43.7) he was enrolled in the ranks of the Companions (hetairoi). S. Pulleyn comments on this matter " $[\mathrm{w}] \mathrm{e}$ also notice that in the account of Arrian and in Plut. Alex. 54 , the person making the $\pi \rho \circ \sigma x u ́ v \eta \sigma \iota \varsigma$ is described as $\dot{\alpha} \nu \alpha \sigma \tau \dot{\alpha} \varsigma$. It is possible that this means that the person got up from the couch only to throw himself

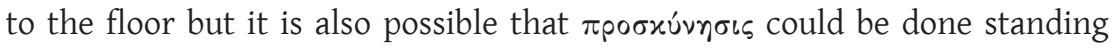
up". ${ }^{32}$ It seems to me, however, that this $\alpha \nu \alpha \sigma \tau \dot{\alpha} \varsigma$ is not related to the posture

Aristobulus or Ptolemy. Plutarch, on the other hand, attributes it to Chares of Mytilene. Their two versions are almost identical in outline and even vocabulary, and it is therefore evident that they had a common source; see Bosworth 1995, 87-88.

31. This Demetrius is alluded to as being among those flattering Alexander at Plut. Adulator 65d.

32. Pulleyn 1997, 193 n. 95. 
of proskynesis at all. It likely serves to illustrate the simple procedure that is described, namely that one had to stand up from the banquet couch before performing proskynessis. We do not have any literary or iconographic evidence from which to infer that one could perform proskynessis even when lying on a couch.

In order to define the posture of proskynesis, we should rely on the context in which it is encountered, as suggested in the previous discussion. In so far as Plutarch's tradition can be trusted, ${ }^{33}$ the banqueter seems to have been holding in his hand a phiale -a shallow bowl- containing wine. Unless we accept at face value the account of Arrian that this container was drained by its wielder, this proskynessis must have been a moderate gesture, as it would have been fairly difficult or even impossible for the banqueter to prostrate himself or to kneel down while simultaneously holding a phiale of wine in his hand. ${ }^{34}$ Raising the right hand to one's lips (whether this represented the sending of a kiss is another matter), most likely supplemented with a little bow where possible, seems reasonable in this scene, and is in agreement with the depiction of this gesture in the Persepolis reliefs. If this is indeed the case, it may explain why it was easy for Callisthenes to escape the king's detection at the banquet. ${ }^{35}$ Had he failed to take on the conspicuous posture of prostrating himself on the ground, even a man in deep conversation might have been aware of it.

33. The discussion here regards Plutarch's version as more trustworthy than Arrian's for the following three reasons: firstly, Plutarch's Life of Alexander reveals its source as Chares of Mytilene's history. Secondly, the action of attendees facing the household shrine (hestia) is omitted in Arrian's account; in other words, Arrian may have condensed the original information more than was necessary. Thirdly, whereas his subjects were bestowed with a kiss by Alexander in Arrian's tradition (a role reversal with regard to Plutarch's version), only Callisthenes tries to offer a kiss to the king; this unnatural exception suggests misinterpretation on the part of Arrian of Chares' original text.

34. Taylor 1931, 264-265 n. 30. According to Theophrastus (apud Ath. 693d), after the proper banquet, the Greeks performed proskynessis to the god of wine and drank a sip of unmixed wine. This ceremony is, at first sight, similar to the situation of Alexander's experiment with proskynessis, but we of course have to distinguish them from each other; the former is a purely religious ritual and is different from the court protocol which Alexander intended to introduce.

35. Bosworth 1995, 89. 
In actual fact, proskynēsis was not an invention of the Achaemenid royal court. ${ }^{36}$ According to Herodotus, Cyrus the Great was expected to be killed soon after he was born, but he fortunately survived this tragic fate, and grew up as the child of a humble herdsman. When Astyages, the Median King, came to know the truth about his survival, he became furious and summoned Harpagus, who was initially charged by the king with the killing of his grandson. The atrocious despot concealed his anger to Harpagus, inviting him and his son to dinner. Without knowing the king's true intention of butchering his son, Harpagus was pleased by the invitation and offered proskynēsis to his master (1.119). Like Herodotus, Ctesias, who stayed at the Persian court for several years and wrote a long treatise on the three successive kingdoms of the Orient, refers to proskynesis a few times in his descriptions of the Median court. The Babylonian governor Nanarus offered proskynēsis to the Median King Artaeus, when he was forgiven by the king for his misdeeds involving the king's Persian friend (F 6b.6, Lenfant). In Ctesias' tradition, Cyrus was not the grandson of Astyages, but a son of a poor couple of a nomadic Persian tribe that was eventually hired by Astyages. When Cyrus was granted a five-month leave from service, he performed proskynēsis before the king (F $8 \mathrm{~d}$.23, Lenfant). Strabo, who does not use the term proskynēsis, asserts:

"The Medes, however, are said to be the creator of customs for the Armenians and also, still earlier, for the Persians, who were their masters and the successors in the authority over Asia...The divine reverence paid to the kings came to the Persians from the

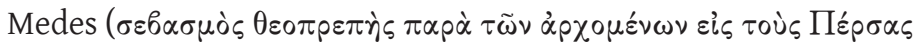

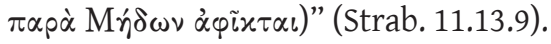

In spite of the fact that the Achaemenid Empire was built by the Indo-Iranian people, the possibility of a Mesopotamian influence, given that region's imperial precedence, cannot be dismissed. ${ }^{37}$ E.J. Bickerman points out a possible link between an ideographic sign in cuneiform and a Sumerian gesture; the verb kurâbu, meaning "to pay homage" or "to pray", represented by the

36. For more on the historical background and institutional character of the Achaemenid royal court, see Brosius 2007; Llewellyn-Jones 2013.

37. For the general view of the Mesopotamian impact on the Achaemenid culture, see e.g. Panaino 2000. 
signs of "a hand" and "a mouth". ${ }^{38}$ This cuneiform sign could in turn represent the archetype of the Achaemenid court proskynesis as it is depicted in the Persepolis reliefs. There is more iconographic evidence than that of letters, however. Quite possibly the most famous example is to be found on the stele of Hammurabi's code of laws (dated to the mid-eighteenth century BC). A relief is sculpted on the upper part of the stela, in which King Hammurabi can be seen standing before the god Shamash, or possibly Marduk, with his right hand turned sideways and raised to his mouth (fig. 6). "The Worshipper of Larsa", a bronze statuette dedicated to the gods for "the life of King Hammurabi" (dated to the early second millennium $\mathrm{BC}$ ) is a figure of a kneeling man, with his right hand turned inward and raised in front of his mouth..$^{39}$ Among inscribed cylinder seals of the Ur III period, some bear the depiction of a presentation scene, in which the owner of the seal is brought before an enthroned figure (a god or king) by an "interceding goddess (LAMMA)"; the owner's left hand is taken by a minor goddess, but his right hand is raised to his mouth (fig. 7. The Morgan Library and Museum, Morgan seal no. 277: a worshipper and owner of the seal, "Ur-Nusku son of Kaka, merchant" is brought to the enthroned deity by an "interceding goddess". "Ur-Nusku" approaches the god with his hand on his mouth). This royal introduction scene was adopted, with some modification, by the Old Assyrian rulers, whose seals include depictions of a man as he is being introduced to a seated figure by a goddess, with his right hand raised up to the level of his face; another goddess can sometimes be seen standing behind the throne, a depiction that is quite uncommon in Ur III seals. ${ }^{40}$

In the Zagros highland region of İzeh, in southwest Iran, a total of twelve Elamite bas-reliefs have been found carved on the sides of cliffs and boulders, spread across four different locations. Among them is the site of Kūl-e Farah, which is believed to have been an open air sanctuary, and provides us with a series of six Middle and Neo-Elamite carvings. Relief IV, although not well-preserved, depicts a procession of individuals taking part in a sacrifice; they perform a gesture with their hands raised to their faces. ${ }^{41}$ Til Barsip, a

\section{Bickerman 1963, 250.}

39. Choksy 1990b, 201.

40. Eppihimer 2013.

41. Matarese 2014, 130. On the site, see Álvarez-Mon 2010. Although the relief I is dated to the Late Neo-Elamite period in accordance with the contents of the Elamite cuneiform inscription engraved over its surface, there is a lack of consensus regarding 
small provincial town that was once one of the palatial centres of the Neo-Assyrian Empire, is known today for its abundant and well-documented remains of wall paintings. In wall paintings from the palace of Tiglath Pileser III (reg. 744-727), the enthroned king can be seen receiving a tribute procession, just as in the relief of Persepolis. One of dignitaries prostrates himself, ${ }^{42}$ while another raises his hand with the fingers and palm turned toward his mouth in deference to the king. ${ }^{43}$ In a relief depicting Sennacherib accepting the surrender of Lachish (dated to the early seventh century and exhibited now in the British Museum), the victorious king is greeted in a formal manner, with the officials before him raising a hand up to their faces; behind them the prisoners of war prostrate themselves in supplication (fig. 8).

Although I have collected only a small number of examples here, the evidence does seem to support M.C. Root's effort of carefully placing Achaemenid royal representation within the preceding Near Eastern tradition. ${ }^{44}$ We do not, unfortunately, have any direct iconographic evidence from the era of the Median kingdom, as suggested by Strabo. Due to the extreme paucity of archaeological and written records -with the exception of the later and at times anachronistic Greek literature- even the very existence of this Median Empire as an organised state has been brought into question. ${ }^{45}$ As such, it is essentially impossible to trace the direct influx of a highly sophisticated protocol from

the dates for the reliefs II, III, IV, V, and VI. Scholars debate on their dates ranging from pre-1000, up to the sixth century BC.

42. A literary expression, "kneeling before him [the king] and kissing his feet", was employed in the text of an Achaemenid artefact in Babylon, i.e. the Cyrus Cylinder (line 18), probably borrowed from the Assyrian literary formulae. It is, however, noteworthy that the visual expression of this act was carefully avoided in the Achaemenid royal representation. For the translation of its text, see e.g. Kuhrt 2007, 70-74.

43. Choksy 1990b, 201, according to whom "The composition of the apadanna reliefs clearly was influenced by the audience scene at Til Barsip". See also Stronach 2002. In the relief of Tiglath Pileser III in the Detroit Institute of Arts, the king, not enthroned, stands before a group of courtiers, one of whom falls down at his feet. The king elevates his right hand and the "vizier" facing the king raises his right hand in a different, reciprocal way: see Goldman 1990.

44. Root 1979.

45. Sancisi-Weerdenburg 1988; Lanfranchi, Roaf, Rollinger 2003. 
the Medes to the Achaemenid court, or to define their role as intermediaries of a Mesopotamian inheritance, to be bestowed in turn upon their successors. Although Strabo's statement cannot be corroborated, we are on the other hand able to firmly place the Persepolitan gesture within the tradition of the Pre-Achaemenid Near East. The most common gesture of reverence that was performed by officials of the Achaemenids and the Pre-Achaemenid Near East toward their rulers was a raised right hand up to the face, sometimes touching the mouth -even if we do not know the exact meaning of the gesture-, obviously contrary to the Persian prostration as depicted on the "Darius Vase". ${ }^{46}$

Nevertheless, this particular gesture of proskynēsis might have been reserved only for higher officials. What of the Greek ambassadors, who in effect were not subjects of the king whose court they attended? According to the account of Herodotus, Persians decreased the amount of honour bestowed according to relative proximity; that is to say, they held the least regard for those who live furthest away from the centre of their empire (Hdt. 1.134). ${ }^{47}$ Did this mean that Greek diplomats were considered inferior to Persians and Medes in terms of the status bestowed upon them? In the relief depicting the surrender of Lachish, the Assyrian king is greeted in a formal manner by his officials, while the prisoners prostrate themselves in supplication. Was there

46. Curtius (8.5.5-24) bases his description of Alexander's introduction of proskynēsis on another source independent from Chares. According to him, Alexander "gave orders for the Macedonians to follow the Persian custom in offering homage to him by prostrating themselves on the ground (ipsum salutare prosternentes humi corpora)". His description should be rejected, because prostrating oneself on the ground to pay homage to the ruler was not the Persian common custom, as discussed here from iconographic evidence. This change in quality was probably derived from the confusion between proskynesis and prospiptein, which will be referred to later. There remains a possibility that the three Persian men in the "Darius Vase" depict a posture other than proskynēsis. For instance, Darius III in the Alexander Mosaic held a similar pose, stretching out his right hand forward, which must not represent proskynēsis (we should keep in mind that unlike the three Persians on the vase, Darius III was not kneeling, as he was mounted on horseback instead). For the interpretation of Darius' act, see e.g. Osada 2012.

47. This centre-and-periphery hierarchy is confirmed also from the Achaemenid royal inscriptions: see Lincoln 2007, 17-32. 
another code of proskynēsis reserved for the Greek visitors? ${ }^{48}$ We should not lose sight of the fact that the Greeks were diplomats rather than war-prisoners, as is the case in Lachish.

As proskynesis was a part of the court ceremony, it must have been governed by strict rules, and this would have been reflected even in Greek sources ${ }^{49}$ In fact, not many pieces of information remain that might shed light on the scene of Greek envoys having an audience with a Persian king; Herodotus is always our most valuable informant on Persian affairs. The Spartans, who had killed the Persian heralds sent by Darius in the late 490s by throwing them into a well, had later sent two Spartan ambassadors, perhaps more accurately described as "scapegoats", to Darius' successor Xerxes, in order to compensate for their wrongdoing. Upon their arrival in Susa, where they were to appear before Xerxes, Herodotus says "when the royal guards ordered them, and tried to force them to fall down and pay proskynesis to the king, their response to this was to declare that they would never do any such thing even if their heads were

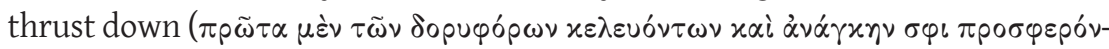

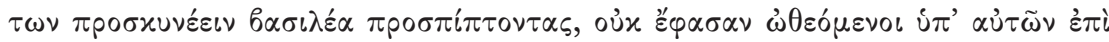

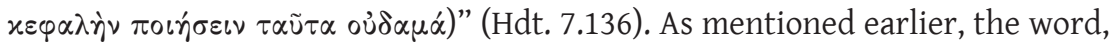
prospiptein (to fall down) is often but not always used in connection with proskynesis, but the concept of prospiptein is similarly complicated. ${ }^{50}$ When the two Spartans reply "even if their heads were thrust down", how far down did they have to lower their heads? Were they expected to put their heads down on the ground by prostrating themselves? Was a mere small bow admissible? Or did the ideal position lie somewhere in between? In order to define this further, we must wait for the next instance of Greeks to come before a Persian king.

Plutarch told of what happened with two Theban ambassadors, Pelopidas and Ismenias -this Ismenias is not the famous politician of the Peloponnesian War, but another lesser-known Theban, and a close friend of Pelopidas- ${ }^{51}$ on

48. Cf. Sachsen-Meiningen 1960, 149-150.

49. See Brosius 2010b.

50. Prospiptein is usually translated as "to fall down", but it can also mean "to kneel

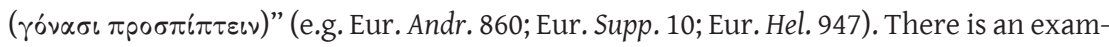
ple that may suggest "to do prospiptein with standing" (Eur. Alc. 164): see Mitropoulou 1975,19 . In this case, prospiptein possibly means "to bow", or merely "to implore".

51. See Binder 2008, 304. 
the occasion of their audience with Artaxerxes II. ${ }^{52}$ "Pelopidas did nothing to disgrace himself; but Ismenias, when ordered to pay proskynesis to the king, threw his ring down on the ground in front of him, and then stooped to pick it

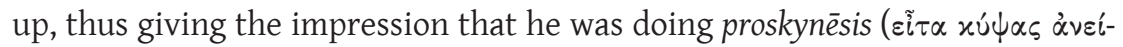

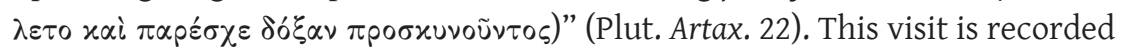
as follows by Aelian, in a more novelistic fashion.

"On arrival he [Ismenias] wished personally to meet the Persian to discuss the business for which he had come. The official who took messages into the king and presented petitioners said to him 'But there is... a traditional custom in Persia that a person who has audience with the king should not talk with him before

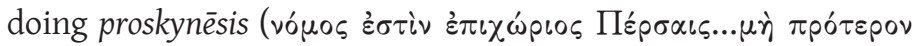

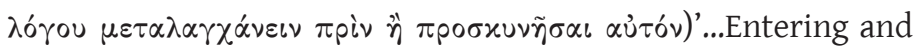
coming into full view of the king, he [Ismenias] took off in secret the ring he happened to wear and dropped it at his feet. Looking down quickly he bent down to pick it up, as if he were perform-

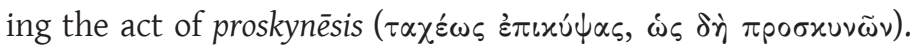
This gave the Persian king the impression of proskynessis ( $\delta \dot{\sigma} \xi \alpha \nu$

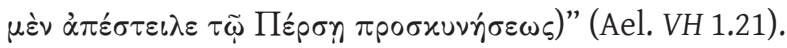

This description allows us to form a more visual image of this practice. Prospiptein is here paraphrased as (epi)kyptein (to bend down). In order to pick up a ring fallen down at one's feet, a little bow is not enough, but at the same time, prostration is not necessary, either; it would be excessive, and Ismenias' deception could not have salvaged his conscience in this case. There may perhaps be a lingering suspicion that Ismenias lied about what he actually did after his return to Greece. We should recall, however, that the scene of prostration before the king, a recurring feature in the iconography of preceding kingdoms, disappeared in Persian royal representations. ${ }^{53}$ In the triumphal relief of the Behistun monument even the rebel leaders, despite being bound in shackles, approach the king on foot with an air of dignity. This might imply the deliberate intention of the Persian rulers to avoid that posture in their court protocol. In the case of Ismenias, a deep bow would have been the most

52. For this audience, see also Plut. Pel. 30.

53. See above, n. 42. 
suitable posture. We cannot of course exclude the possibility of kneeling, but a deep bow seems more appropriate to me, since the basic pose of Persian proskynesis before the king was a small bow with a hand raised in front of the mouth, as discussed above. The depth of the bow probably depended on how intimate they were with the king -unfortunately we cannot deduce from the description of this particular audience whether foreigners were also required to offer a kiss..$^{54}$

\section{Greek abhorrence to the proskynēsis of Persian protocol}

The next question to be addressed is why Greek visitors were so unwilling to accept the practice of proskynēsis in the first place, viewing it as an abhorrent Persian protocol, given the assumption that in at least some instances it may have represented no more than a bow (with the probable addition of a hand raised to the mouth). The custom of proskynesis (bowing to one another) on the streets was "known nowhere in Greece", according to Herodotus (2.80). Prosky$n \bar{e} s i s$, in addition to yielding one's place in deference and the giving of a gift that is of high value in all places, was not the Greek manner of honouring, and practiced only among the barbarians (Arist. Rh. 1.5.9, 1361a34-7). Before the battle of Cnidus, Conon requested an audience with Artaxerxes II. Despite being personally willing, he did not perform proskynessis himself, on the grounds that his countrymen might be shamed by his compliance with a barbarian tradition, as opposed to adhering to the traditions of Athens (Nep. Con. 3.3-4). Wherever "nomos is king of all" (Hdt. 3.38), people would be averse to complying with a custom that appears strange and ridiculous to them.

54. Although Plutarch and Aelian were much later authors, they must have taken this episode from the same source, which is most likely Dinon's Persica: other possibilities cannot be excluded, but his name is referred to at the beginning of Plut. Artax. 22 . Athenaeus (2.48d-f) also makes an allusion to similar examples of the royal audience of Greek ambassadors, but he probably relies on a source different from theirs (he refers to the name of Phaenias, the student of Aristotle, and Heracleides of (yme); for further discussion of the source, see Binder 2008, 294-299. Dinon lived in the second half of the fourth century, and wrote a history of Persia up until Artaxerxes III's reconquest of Egypt in 343/2. Dinon enjoyed less popularity, but has a much better reputation than Ctesias; his Persica was a main source for Plutarch's Life of Artaxerxes. Nepos, for instance, claims that on Persian matters he trusts Dinon most (Con. 5.4). For Dinon and the use of his Persica, see Stevenson 1997. 
In the case of proskynēsis, however, they seem to have had a much deeper cause not to accept it. When Persian guards enforced the practice of proskynessis in the presence of Xerxes, two Spartans resisted the guards by saying, "it was

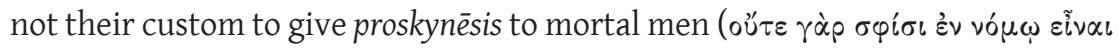

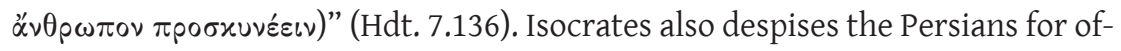
fering proskynēsis before the mortal king and hailing him as a god (Paneg. 151). At the assembly in the middle of the camp, Xenophon, elected as one of the new commanders, gave a speech to his soldiers and addressed them as those who "perform proskynesis to no human creatures as master, but to the gods

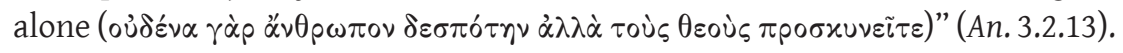
It would seem that among the Greeks, proskynesis was reserved solely for the gods. In actuality, their hesitation to offer proskynessis to the Persian king was not motivated by religious reasons alone.

Although Pelopidas the Theban also opted out of the custom of proskynēsis before the king, Plutarch does not give his reason for doing so (Plut. Artax. 22.8). His colleague Ismenias, on the other hand, used a ruse so as to cause "no

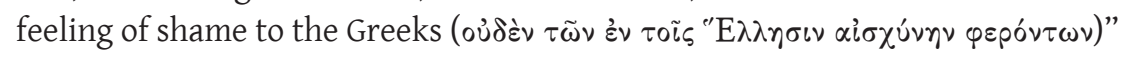
(Ael. VH 1.21). But in what respect would it have been a disgrace to the Greeks? Themistocles was a political refugee to Persia, and is known to have acquiesced to the requirement of proskynessis. Plutarch quotes this episode from a late fourth-century historian, Phaenias of Eresus: before his meeting with the king, Artabanus, the Achaemenid chiliarch, spoke about his position on the matter, saying it is required in Persia for the person who wishes to be presented before the king "to honour the king and to pay proskynesis to him as the image of the

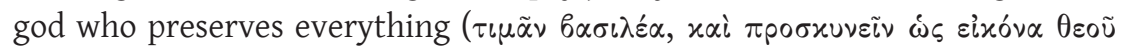
$\tau \circ \tilde{v} \tau \dot{\alpha} \pi \dot{\alpha} \nu \tau \alpha$ $\left.\sigma \dot{\omega} \zeta_{0 \nu \tau o \varsigma)}\right)$ ", even if the Greeks do not wish to do so, as they "ad-

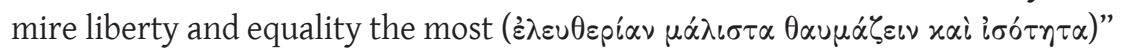
(Phaen. FGrH 1012 F 20, apud Plut. Them. 27.4). It is notable that the religious argument of offering proskynesis exclusively to immortals has been replaced here with a social polemic of Greek freedom against Persian enslavement.

The comparison between Persian proskynessis and Greek freedom is a topos in Xenophon as well. In order to persuade the Persian satrap Pharnabazus to become his "guest-friend", the author makes Agesilaus say, "it is now within your power, by joining us, to live in the enjoyment of your possessions without having to pay proskynesis to anyone, or to have any master. Moreover, to be free

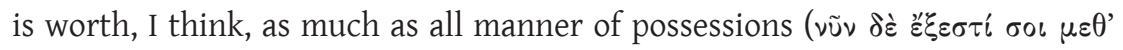




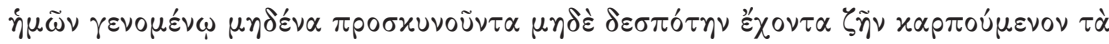

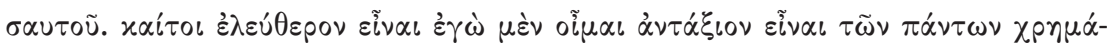
$\tau \omega v)$ " (Hell. 4.1.35). Here proskynessis is juxtaposed with being free, and treated as synonymous with subjugation. ${ }^{55}$ This view of a dualistic opposition is clearly demonstrated in Heliodorus' Aethiopica, although it is a late Roman romance: when Theagenes, a young Greek, was informed of his legitimate status as a slave to Arsace -the wife of the Persian governor in Egypt- as a result of being a Persian prisoner of war, Achaemenes, the son of her chamberlain, mocked him by saying, "you who were so proud and lofty of late, the free man, without bending your neck, who thought it intolerable to put your head into proskynessis ( $\delta$ tòv

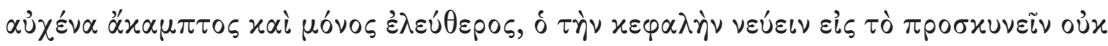
$\dot{\alpha} \vee \chi^{\prime}(\mu \varepsilon v o s)$, surely now you will have to stoop, or else by my blows you will be taught how to do so" (7.25.1).

As shown in Aeschylus' Agamemnon, "nor, like some barbarian, grovel be-

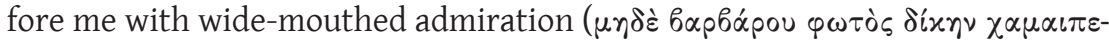

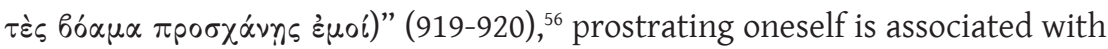
barbarians, and not least with their servility, in stark contrast to the Greek stance of freedom. Although we have already discussed that the proskynesis of Persian court protocol did not necessarily require prostration, this practice was nevertheless strongly associated by Greeks with the barbarian mind of the Persians. As for Alexander's experiment with proskynēsis, two traditions are handed down to us. One of them is relayed to us by Chares of Mytilene, which we discussed previously. The other story, as relayed by Arrian (Anab. 4.10.5-12.2) and Quintus Curtius Rufus (8.5.5-24), is a long speech opposing the practice of proskynesis as given by Callisthenes, the "official historian" for Alexander (Just. 12.6.17). ${ }^{57}$ Although modern scholars have a tendency to dis-

55. See also Xen. Ages. 1.34: During and after 396, when Agesilaus saved Greek inhab-

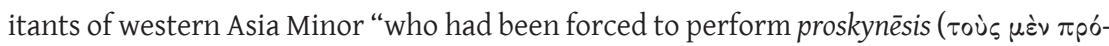

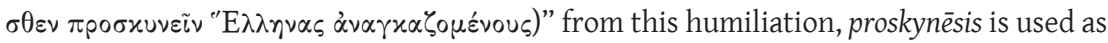
a synonym for Persian subjugation.

56. For more on these lines, see Couch 1931.

57. Although it appears at a superficial glance that this speech is inconsistent with the story attributed to Chares, these two observations can be explained as pertaining to events taking place on different occasions, and as such would not constitute an inconsistency at all. Cf. Bosworth 1988b, 285-286; Bosworth 1995, 88. According to Bosworth, the episode recorded by Chares is about an experiment involving a small, closed circle, 
miss this as unhistorical and a rhetorical fabrication, and the source or sources cannot be identified (according to Arrian it was a widely known story),,$^{58}$ A.B. Bosworth argues that "the historical core was variously adapted", and "Arrian's material is more Hellenistic in flavour [than Curtius'] and could very well echo the contemporary debate on the propriety of deifying a living man" ${ }^{59} \mathrm{As}$ such, I would like to glean contemporary sentiment on proskynesis from this debate. The outline of the debate is that, in the absence of Alexander, Anaxarchus gives a speech in which he argues that Alexander had performed such great feats, surpassing even Heracles and Dionysus, that he was deserving of being worshipped as a god. Opposing this, Callisthenes makes a speech that pleased the Macedonians. His opposing arguments were twofold: Callisthenes claims a sharp demarcation between respects paid to the gods and those paid to men..$^{60}$ Among many honours reserved for the gods, "the most significant

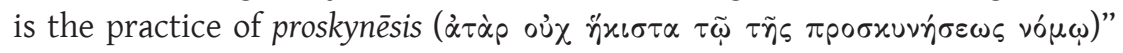

that preceded the occasion of the public ceremony, where Callisthenes presented his rhetorical opposition to the introduction of proskynessis.

58. Plutarch does not refer to this debate in detail, but his comment on Callisthenes implies that he was also aware of it. He refers to Callisthenes as "forcefully and like a philosopher refusing to perform proskynesis", "having openly expressed what the noblest and oldest of the Macedonians were resenting in secret", and "he destroyed himself, because he was thought to have forced the king, rather than persuaded him" (Plut. Alex. 54.3). These acts do not appear in the Chares story, but only in the account of the Callisthenes' debate as given by Arrian (and Curtius): see Badian 1981, 49.

59. Bosworth 1995, 77-78. The most obvious discrepancy between the accounts of Callisthenes' speeches by Arrian and Curtius is that the latter's Callisthenes makes a concession to an apotheosis after death (8.5.16), which became more common during the early Roman imperial period: see Bosworth 1988a, 113-123. Balsdon (1950, 371-372), for instance, takes a negative view of its historicity, but more recent scholarship (e.g. Faraguna 2003, 118) tends to follow Bosworth.

60. The absolute gulf drawn between god and man is also apparent in e.g. Pindar; he concedes the human ability to in some ways approach the immortals by their greatness of mind or nature (Nem. 6.4-6), while at the same time insisting on the inaccessibility of the brazen heaven, even to those most felicitous of mortals (Pyth. 10.27; cf. Nem. 11.15-16). Muccioli (2016) argues that although Persian proskynēsis might have been a mere court ritual, there remained room for Callisthenes and his Graeco-Macedonian colleagues to (mis)understand it as a religious practice. 
(Arr. Anab. 4.11.2). The other point is that it would be impossible "to compel

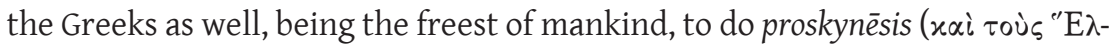

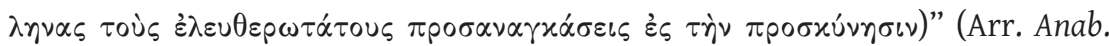
4.11.8). Here, the reasons for not tolerating proskynēsis are clearly indicated as two interconnected but distinguishable issues, the first being religious in nature ("we do not do proskynessis because we offer it only to the gods, and the king is not a god"), and the second being a social, secular motivation ("we do not offer proskynēsis, because we are free").

In the case of the former reason, it is possible to point out a discrepancy between Greek perception and Persian cosmology. Although Aristotle, with

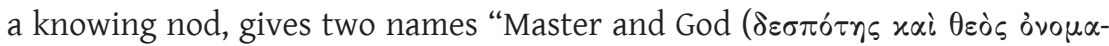

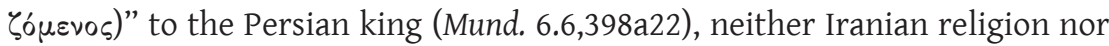
the Achaemenid royal inscriptions indicate the connotation of a divine king. ${ }^{61}$ For instance, in the monumental trilingual inscription at Behistun, Darius says, "I am king by the will of Ahuramazdā. Ahuramazdā granted me kingship" (DB1.11-12, translated by R.G. Kent). This clearly demonstrates that Darius was no more than a human agent, and kingship is bestowed upon him by the grace of Ahuramazdā. ${ }^{62}$ In proof of this, the reverent gesture to deities is distinguished from that to the kings in the Achaemenid Persian iconography; the former is the raised hand with the palm turned outward or sideward, the latter being with the palm turned inward. ${ }^{63}$

It is important to note that proskynesis was not reserved exclusively for the Great King; the Persian queen also had the right to receive proskynesis (Dinon, FGrH 690 F 27). ${ }^{64}$ Proskynessis was not even a privilege bestowed solely on the

61. Tuplin 2017. Contrary to Aristotle, our Greek sources generally regarded the Persian king as godlike (isotheos), rather than a god itself: see Gow 1928, 136; Badian 1996.

62. For the ideology of the Achaemenid kingship as the God's chosen, see Lincoln 2007, 33-49.

63. Choksy 1990a.

64. For commentary on this fragment of Dinon, see Lenfant 2009, 233-236. According to Theopompus, Harpalus the treasurer of Alexander sent for his mistress Glycera from Athens; when she stayed at a palace in Tarsus, she was given proskynēsis and hailed as queen (basilissa) by the locals (Theopomp. FGrH $115 \mathrm{~F} 254 \mathrm{~b}$ ). The female right of receiving proskynēsis is attested in a Greek romance. In Heliodorus' Aethiopica (7.19.1), the young Greek Theagenes was instructed by eunuchs to perform proskynēsis when entering the 
highest couple of the royal family. When the treasonous plot of Orontas was revealed to Cyrus the Younger, he was sentenced to death by a court martial. Before he was taken to be executed, "when those who had previously paid proskynēsis to Orontas saw him, they offered proskynēsis even then" (Xen. An. 1.6.10). Although he was a member of the royal family, Orontas was no more than a subordinate to the young prince Cyrus; even so, he deserved proskynesis (Xen. An. 1.6.1-6). If proskynēsis had been an instrument that served to elevate the king to the level of a god, would proskynesis being granted even to royal inferiors not have devalued it? An episode from Plutarch's Life of Aristides (5.7), in which a Persian mistook Callias for the local Athenian king and paid proskynessis to him, implies Persian recognition that this act was to be performed on the basis of generalised social inequality, rather than a specific ruler-ruled relationship in the Achaemenid context. We should remember also that even nobility on the street could receive proskynessis from passers-by (Hdt. 1.134). Proskynessis in the Persian context was a simple secular practice that served as an assertion of the asymmetric relationship between individuals of unequal social status. ${ }^{65}$

This may paradoxically offer an explanation of Greek attitudes regarding proskynessis before the king. For those unaware of its secular aspects, to offer proskynesis to the Persian king would cause religious offense, as they reserved this practice only for the gods. Even for those who did understand the secular aspects (some Greek visitors were likely recipient of explanation offered

audience room of Arsace, the Persian mistress of the Achaemenid Egyptian satrap. Theagenes refused to do so, just as the Greek delegates to the Persian kings. Depictions of the female audience scene is also found both in the centre (PFS 77*; AO 22359 - a chalcedony cylinder seal from the De Clerq Collection, Louvre) and periphery of the empire (the west face of the Harpy monument from Xanthus in Lycia; two funeral stelae from Dascylium). PFS 77* depicts a woman seated on an elaborate throne, receiving a female visitor who holds an object (a bowl or a stylised flower) in her hand. An anthemion stele from Dascylium shows a woman enthroned in the centre, and welcoming two female guests, one of whom raises her hand up to her shoulder. See further, Brosius 1996, 86; 2010a. For the relief of the anthemion stele from Dascylium, see Bakır 2001, 174.

65. The practice of offering proskynessis at the occasion of a new king's coronation (see the beginning of the preceding section) would have signified the process of affirming a renewed hierarchy between the king and his subjects. 
by Persian intermediaries), the ritual remained intolerable. The Greeks, who believed in the independent status of their cities, and their ostensible equality with respect to the Persian king, continued to assert their freedom in opposing Persian subjugation. To comply with the court ceremony of proskyne $\bar{e}-$ sis would be tantamount to a resignation of their freedom, and acceptance of their social inferiority to the Persian king. On the other hand, Greeks came to the king's court with a petition or request. Given this difficult dilemma -we should remember here that those who were willing to perform proskynesis before the king, Conon and Themistocles, were not diplomatic representatives but persons in exile, exempted from political responsibility with respect to their native city-, they would have needed a plausible excuse for disregarding this practice of social confirmation: they offered proskynessis only to the gods, and not to mortals.

\section{Proskynēsis as a religious practice}

In the preceding text I discussed several instances where Greeks referred to proskynesis being a religious practice, as a reason for rejecting the requirement of proskynēsis before the Persian king. To further understand the Greek sentiment against this secular Persian ceremony, it is necessary to examine the characteristics of proskynēsis as a religious tradition.

Unlike the act of proskynessis performed before the Persian king, we have quite a few pieces of evidence concerning proskynesis to the gods. In Characters (16.5), Theophrastus considers as superstitious persons those who, after anointing them, knelt down and performed proskynesis to smooth stones set up at three-way junctions; these stones would have represented the chthonic goddess Hecate. ${ }^{66}$ The Pythagoreans are said to have gone from their homes directly to their place of prayer, having prepared their minds in advance, and

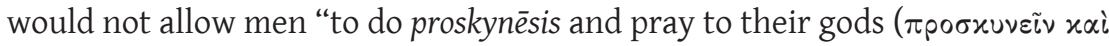

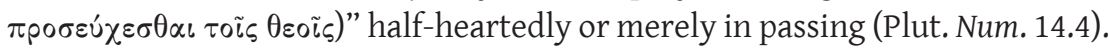
Examples of this kind can also be found in theatre plays. ${ }^{67}$

66. See Ussher 1993, 142-143. Being three-formed, Hecate was associated with the three-way junction (cf. Ath. 7.325a). Clemens of Alexandria also criticises those giving proskynessis to smooth stones as being superstitious (Strom. 7.4).

67. E.g. Ar. Eq. 156; Soph. OC 1654f. For the proskynessis in the Greek religious context, see also Delatte 1951. 
In Greek literature, Persians also give proskynēsis to divine entities. In Aeschylus' Persians, those revering the deity responsible for freezing the Strymon River before the coming of winter, pray to the gods in supplication and

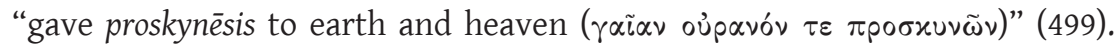
When he was young, Cyrus the Great is said to have observed an eagle flying up from the east as it caught sight of a hare; the eagle swept down and seized upon it, and carried it up and away to a hill, where the bird disposed of its prey with pleasure; "recognising it as an omen, he was pleased and did proskynēsis

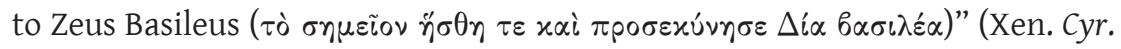
2.4.19). Upon visiting his ancestral home as an adult, Cyrus witnessed thunder and lightning to his right side, and he performed proskynēsis; ${ }^{68}$ in the same moment auspicious birds settled on his home, presaging that he would reach $\mathrm{Pa}-$ sargadae (Ctes. F 8d.41, Lenfant). In short, at least according to Greek sources,

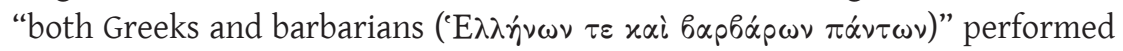
proskynēsis as a religious rite (Pl. Leg. 10.887e).

Given that Greeks did perform proskynessis before their gods, what was the most common posture that they assumed before their gods and goddesses? "All of us men stretch out our hands to the sky when praying", as Aristotle states in a generalisation (Mund. 6.6, 400a16). This is corroborated by various surviving visual examples. An excellent three-dimensional representation of this is a Roman copy in bronze of a fourth-century Greek statue known as "Betende Knabe (Praying Boy)". It is attributed to Boidas, son of Lyssipus, and now stands exhibited in the Pergamum Museum of Berlin. There are also examples of images depicting this posture in votive offerings. In an Attic red-figure amphora (London E 291), a man named Phineus raises his hands in prayer while he addresses the gods. Standing with one or two hands raised was the most common posture in Greek prayer. ${ }^{69}$

Although it is less common, votive offerings also depict images of kneeling. ${ }^{70}$ This posture would seem to be more directly associated with proskynesis. F.T. van Straten, however, claims that it is often associated with appeals of

68. An omen coming from the right-hand side was seen as a harbinger of good fortune: see Plut. Them. 13.3; Plut. De gen. 594e.

69. See further Aubroit-Sévin 1992, 125-145.

70. Catalogues are presented by van Straten 1974; Mitropoulou 1975, 19-58. They represent no more than a tiny minority (some twenty or thirty) of surviving reliefs, showing kneeling worshippers. 
a more urgent nature, hiketeia (supplication). ${ }^{71}$ The ideal posture of a hiketēs (suppliant) is demonstrated by Thetis: when she came to Olympus in order to supplicate to Zeus, she found him sitting; she herself also crouched in front of him and touched his knees with her left hand, while taking hold of his chin with her right hand (Hom. Il. 500-502). It is true that in the hiketeia iconography, women are represented more often than men; in other words, kneeling might be considered as an effeminate act from an iconographic viewpoint. ${ }^{72}$ Likewise, in literary examples women kneel more often than men to a god or hero, whether he is represented by his cult-image, altar or tomb..$^{73}$ of more importance, however, is the fact that hiketai (both male and female) can kneel not only before divinities, but before mortal men as well. ${ }^{74}$ This seems to be an apparent contradiction to the statement that proskynesis before mortal men is inadmissible - it is admissible only in the context of hiketeia.

In actuality, no fifth- or fourth-century iconographic testimony has been found that can be precisely identified as an example of proskynessis to deities or altars. ${ }^{75}$ One reason for this is the fact that we do not know exactly what kind of gesture proskynēsis represented (see the first section of this paper). Another reason may be implied by the nature of proskynēsis as a religious gesture. It was in several cases shown as a sudden and reflexive action, performed in response to an unexpected event or occasion; in the Cyropaedia, Cyrus was surprised and pleased by an unexpected omen and did proskynessis, and the Pythagoreans criticised those who were not prepared for prayer and offered proskynesis on the streets instead. We should also keep in mind that proskynessis could be

71. van Straten 1974, 183-184.

72. Approximately one tenth of kneeling worshippers are male, the majority being female. See e.g. Aesch. PV 1005: importuning "with the hands upstretched in a woman's

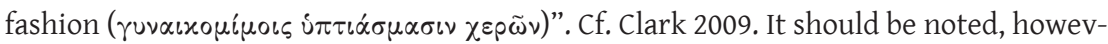
er, that the gesture of kneeling in the votive reliefs is rather rare to begin with, and it is therefore difficult to identify any general trend among them.

73. See Mitropoulou 1975, 17-18. Male kneeling worshippers appear in Polyb. 32.15.7; Ar. Eq. 30; Eur. El. 510.

74. Likely the most famous example is Priam's supplication to Achilles (Hom. Il. 24.477ff.). For more on hiketeia, see Gould 1973.

75. van Straten 1974, 159-160: as for the gesture of kissing one's own hand, "it does not occur in the numerous 5th and 4th century Greek representations of worshippers approaching deities (or altars)". 
performed even in an emergency, such as that of an impending arrest (Luc. Demosth. 49), or in the middle of a camp surrounded by one's enemies (Xen. An. 3.2.9: see below). This characteristic of proskynessis would have hindered its use in votive reliefs; the scenes they depict would have been carefully staged, on account of their expected longevity, and their considerable expense. ${ }^{76}$

In spite of their claims to the contrary, Greeks did in fact perform proskynessis to other Greek mortals in addition to their deities. We have only a few exceptional examples of this, but they are nonetheless significant for our understanding of the characteristic nature of proskynessis as part of Greek religious practice. In Plato's Republic, Socrates suggests the banning of poetry; if a man with the ability to transform himself into all sort of characters and to imitate all manner of things were to arrive in their state and demonstrate his skill, Socrates states ironically that its citizens would do proskynēsis to him for being a wondrous and delightful creature, and send him away to another city all the same (3.398a). This is of course a work of fiction, and it is difficult to understand why Socrates (or Plato) would choose to employ the verb "to do proskynēsis" in this specific context. To give proskynessis to a mortal was in this case probably intended as a satirical exaggeration, meant to express contempt for the imitators. Plato uses proskynēsis as an act of reverence to a mortal human once more in the same work: ${ }^{77}$ when Guardians fight bravely and fall in battle, those of their state should "attend to them until the end of time as divine spirits, and do proskynēsis at their grave (

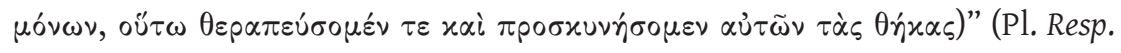
5.469a-b). Here the function of proskynesis is more obvious; the act serves to elevate mortal Guardians, although super-human in nature, to those revered as divine spirits after the event of their death. There are additional examples to be found in works of fiction, such as in Chariton's Greek romance, Chaireas and Callirhoe, written in the late Hellenistic or early Roman period but borrowing its historical setting from the reign of Artaxerxes II. The heroine of this romance, Callirhoe, was offered proskynēsis many times by both Greeks and Persians, owing to her divine beauty, which was said to be so great as to rival the

76. van Straten (1981) provides us with an overview on Greek votive offerings. For the cost of votive reliefs, see also van Straten 1974, 184-187.

77. Plato mentions proskynein three times in the Republic, but in the remaining instance (5.451a) proskynēsis is paid to a goddess, Adrasteia. 
goddesses Artemis or Aphrodite (1.1.16; 3.2.14; 4.1.9; 5.3.9; 5.9.1). Likewise, in Heliodorus' Aethiopica (3.17.2), Calasiris, the Egyptian priest of Isis, was all but offered proskynēsis by a young Greek named Theagenes; when Calasiris told him that he was in love with a beautiful girl named Chariclea, Theagenes took this knowledge as having been imparted to him by God; here also, Calasiris is almost elevated to something divine.

Another example of proskynēsis being given to a mortal human occurred in the midst of the camp of the Ten Thousand. After their generals and commanders were captured, the Greek mercenaries were brought to desperation by the hopelessness of their situation. It was at this point that they gathered for a meeting:

"Just as he [Xenophon] was saying this [the word $\sigma \omega \tau$ inpias], someone sneezed; upon hearing this, all soldiers at once made

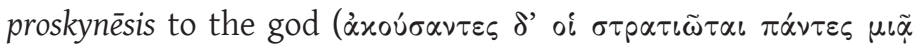

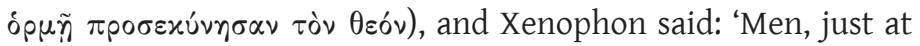
the moment when we were discussing our salvation, an omen from Zeus the Saviour has been revealed to us' "(Xen. An. 3.2.9).

In Greek culture, sneezing was mostly regarded as an omen of good luck. ${ }^{78}$ A famous episode appears in the seventeenth book of Homer's Odyssey: when Penelope and Eumaeus were talking about Odysseus while suitors feasted in the hall, Telemachus sneezed loudly; Penelope laughed and said to Eumaeus: "Did not you notice that my son sneezed on all I have said? That may mean that death is inevitable for all these suitors. Not one of them shall escape their fate" (Od. 17.545-547). A more historical record is brought forth clearly by Plutarch. When Themistocles was making a sacrifice preceding the battle of Salamis, three Persian prisoners of war were brought before him. "Just as Euphrantides the diviner caught sight of them, a great flame shot up from the sacrificial victims, and a sneeze from the right-hand side brought forth its good omen". Euphrantides took Themistocles by the hand and told him to consecrate the young Persians, and to sacrifice them all to Dionysus Omestes

78. For a general discussion on the divinatory character of sneezing, see Pease 1911; van der Horst 2013. A sneeze could possibly be interpreted as either good and bad omen, depending on the circumstance: see e.g. Plut. De gen. 581a-b. 
(the Eater of Raw Flesh), for doing so would bring salvation and victory to the Greeks (Them. 13.2).

As was mentioned previously, proskynēsis must have been a reflexive action, performed in response to an unexpected event. In the case of Anabasis, the Greek mercenaries paid proskynessis to the omen of luck, which was not at all expected. In comparing this proskynēsis as analogous to saying "Bless you!", H. Bowden maintains: "[i]t is hardly likely to involve prostration, or indeed to be an action that a Greek would be worried about doing spontaneously under any circumstance. Above all the story is evidence that not all uses of the word

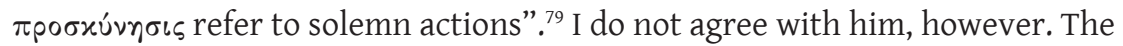
Greek mercenaries must have been greatly moved, awed by the divine coincidence that a portentous word and a sneeze came about in the very same instant, so as to corroborate each other, and they responded with this action in a reflexive but solemn manner (although it remains true that we do not know exactly what kind of action they performed).

Xenophon states that the Greeks paid proskynēsis to Zeus the Saviour, but there would not have been a cult statue or image of the god available to them at that moment, given the fact that they found themselves in the midst of a Mesopotamian field, and in a state of considerable crisis. "The Greeks", Athenaeus states (2.66c), "regarded the head as sacred and they did proskynēsis to the sneezes that erupted from it." The Aristotelian author of the Problemata likewise spends a long chapter on discussing, in a pseudoscientific manner, the various aspects of sneezing. With regard to the question of why the emission of breath such as wind or eructation are not regarded as sacred, but that of a sneeze is regarded as such, he answers that sneezing originates from our most divine part, referring to the head, and as such "people pay proskynessis to breath

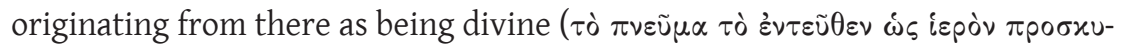

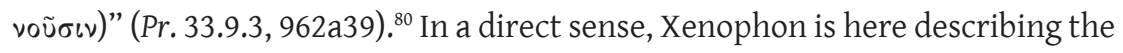
scene where the Greeks gave proskynesis to the man who sneezed in that most significant moment, saying that, in their mind they were performing proskynesis to the god above, regarding him as sacred. In short, proskynessis was an unexpected, reflexive act that the Greeks could employ to raise an object of proskynessis up to the level of being sacrosanct or divine.

79. Bowden 2013, 61.

80. See also Pliny (HN 2.40.107), who implies this custom (adorare cum sternuerit). 


\section{Conclusion: The proskynēsis problem again}

I would like to conclude at this point by stating that there were two distinct acts referred to by the classical Greeks as proskynessis. Despite these forms of proskynesis being entirely different both in the situation they occurred and in the intent of their function, they would have had a posture in common. This resulted in the two acts sharing the same name, which is the cause of much confusion for us, and even for the Greeks themselves. In writing this paper I myself struggled with the topic of proskynessis, which could best be described as a tangled affair.

In a religious context, the Greeks employed a gesture of proskynēsis that was performed when addressing a divine entity. Although literary evidence testifies to proskynessis varying from a light bow, raised hands, to kneeling or prostration, it had an element of unpreparedness; it was a reflexive action in reaction to an unexpected occurrence. This is the reason for us not having any iconographic evidence that would allow us to positively identify it among votive offerings, which came at considerable expense, and thus were designed with forethought and great care. As a gesture, proskynēsis often involved the lowering of the head, but how deeply was not important. If they found themselves in a state of danger or emergency, or were otherwise occupied or engaged in travel, a small bow would have sufficed. Upon wishing to express admiration for the divine with all their heart, they might have prostrated themselves. The essential point, however, is that by offering proskynessis, the object of this act of reverence was raised up and recognised as something sacred or divine.

On the other hand, there existed a custom in the Persian court that those in the presence of the king were expected to perform a particular action, most likely represented by the posture of a bow with a hand raised up to the mouth. Although its Persian proper name has since been lost to us, the Greeks also called this gesture proskynesis, on the basis that its outward appearance, by coincidence, bore a likeness to their own religious proskynessis. The depth of the bow would have depended on the ethnicity of those performing it (Persian, Median or Greek etc.) and their relative status (an Achaemenid subject or a foreign ambassador). Greek ambassadors, who would have come to Susa for the purpose of petitioning assistance from the Great King, might have been required to make a deeper bow than the grand marshal as shown in the Persepolis reliefs, but even then prostration may not have been required. In contrast to the Greek version, this Persian proskynessis was a rather secular practice, 
serving to authenticate social hierarchy between superiors and inferiors. Despite this fact, Greeks remained hesitant to accept the Persian form of proskynessis, on the religious principle that proskynesis is to be reserved exclusively for the divine. This can actually be interpreted in two distinct ways. The first is to assume that their reasoning was purely religious, just as they claimed; they were not content to raise the mortal Persian king up to the level of a divine being, by offering proskynēsis before him. An alternative interpretation presents the possibility of a more subtle, pragmatic motivation: namely, that Greek ambassadors were unwilling to accept the social and political inequality between themselves and this powerful king. Necessity forced them to seek an audience before the king, but they remained loath to accept the insult that offering proskynesis would cause to the belief of their perceived freedom from Persian subjugation. The problem of proskynesis emanated from the cultural and intellectual gap that existed between Greek religion and the Achaemenid court protocol, further exacerbated by the political tensions that occur when ostensibly independent states are pitted against a powerful empire. ${ }^{81}$

$$
\begin{array}{r}
\text { Takuji Abe } \\
\text { Kyoto Prefectural University } \\
\text { tabe@kpu.ac.jp }
\end{array}
$$

81. The proskynēsis problem continues after the Achaemenid period. For proskynēsis in the Parthian and Sassanid periods, see Sachsen-Meiningen 1960, 154-166. 


\section{Summary}

Greek ambassadors who were granted an audience before the Persian King were required to observe a certain form of court ritual. Although the Persian proper name for this ritual has since been lost to us, the Greeks called this act of homage proskynesis; a term normally understood to refer to the act of "falling down" and prostrating oneself before the king. At the same time, the Greeks employed a gesture also called proskynēsis, which was performed when addressing a divine entity. These two acts, while different in their functions, shared the same name on the basis that their outward appearances bore a coincidental likeness to each other. Greek ambassadors, who would have come to Susa for the purpose of petitioning assistance from the Great King, were rigorously hesitant to follow the Persian practice, arguing that the religious practice of proskynessis was reserved exclusively for the divine among them. In this paper, I endeavour to elucidate the true nature of this Persian court protocol, and to show why the Greeks were so unwilling to perform this ceremonial act. I conclude that the normal posture of the Persian proskynessis was most represented by that of a bow with a hand raised up to the mouth, the depth of the bow being dependent on the ethnicity of those performing it and their relative status. In contrast to the Greek version, this Persian proskynessis was a rather secular practice, serving to authenticate social hierarchy between superiors and inferiors. Even though some of the Greek ambassadors must have been aware of this, or perhaps as a direct result of this understanding, they remained loath to accept the insult that offering proskynesis would cause to the belief of their perceived freedom from Persian subjugation. 


\section{Bibliography}

Allen, L.K. 2005. "Le roi imaginaire: An Audience with the Achaemenid King", in O. Hekster, R. Fowler (eds.), Imaginary Kings: Royal Images in the Ancient Near East, Greece and Rome (Oriens et Occidens 11). Stuttgart, 3962.

Álvarez-Mon, J. 2010. "Platform Bearers from Kūl-e Farah III and VI", Iran 48, $27-41$.

Anti, C. 1952. "Il vaso di Dario e i Persiani di Frinico", ArchCl 4, 23-45.

Asheri, D., Lloyd, A., Corcella, A. 2007. A Commentary on Herodotus Books I-IV. Oxford.

Aubriot-Sévin, D. 1992. Prière et conceptions religieuses en Grèce ancienne jusqu'à la fin du Ve siècle av. J.-C. (Collection de la Maison de l'Orient méditerranéen ancien 22, série littéraire et philosophique 5). Lyons.

Badian, E. 1981. "The Deification of Alexander the Great", in H.J. Dell (ed.), Ancient Macedonian Studies in Honor of Charles F. Edson. Thessaloniki, 27-71.

Badian, E. 1996. "Alexander the Great between Two Thrones and Heaven: Variations on an Old Theme", in A. Small (ed.), Subject and Ruler: The Cult of the Ruling Power in Classical Antiquity (JRA Suppl. 17). Ann Arbor, 11-26.

Bakır, T. 2001. "Die Satrapie in Daskyleion", in T. Bakır (ed.), Achaemenid Anatolia. Proceedings of the First International Symposium on Anatolia in the Achaemenid Period, Bandirma, 15-18 August 1997. Leiden, 169-180.

Baldwin, B. 1969. "The Authorship and Purpose of Lucian's Demosthenis encomium", Antichthon 3, 54-62.

Balsdon, J.P.V.D. 1950. “The 'Divinity' of Alexander”, Historia 1, 363-388.

Bickerman, E.J. 1963. "À propos d'un passage de Chares de Mytilène", PP 18, 241-255.

Binder, C. 2008. Plutarchs Vita des Artaxerxes: Ein historischer Kommentar. Berlin.

Bosworth, A.B. 1988a. From Arrian to Alexander: Studies in Historical Interpretation (Oxford Scholarly Classics). Oxford.

Bosworth, A.B. 1988b. Conquest and Empire: The Reign of Alexander the Great. Cambridge.

Bosworth, A.B. 1995. A Historical Commentary on Arrian's History of Alexander, Vol. 2. Oxford.

Bowden, H. 2013. "On Kissing and Making up: Court Protocol and Historiography in Alexander the Great's 'Experiment with Proskynesis”', BICS 56, 55-77.

Brosius, M. 1996. Women in Ancient Persia (559-331 BC) (Oxford Classical Monographs). Oxford. 
Brosius, M. 2007. "New out of Old? Court and Court Ceremonies in Achaemenid Persia", in A.J.S. Spawforth (ed.), The Court and Court Society in Ancient Monarchies. Cambridge, 17-57.

Brosius, M. 2010a. "The Royal Audience Scene Reconsidered”, in J. Curtis, S. Simpson (eds.), The World of Achaemenid Persia: History, Art and Society in Iran and the Ancient Near East. London, 141-152.

Brosius, M. 2010b. “Das Hofzeremoniell”, in B. Jacobs, R. Rollinger (eds.), Der Achämenidenhof/The Achaemenid Court. Akten des 2. Internationalen Kolloquiums zum Thema "Vorderasien im Spannungsfeld klassischer und altorientalischer Überlieferungen”, Landgut Castelen bei Basel, 23.-25. Mai 2007 (Classica et Orientalia 2). Wiesbaden, 459-471.

Chantraine, P. 1968-1980. Dictionnaire étymologique de la langue grecque: Histoire des mots, 4 vols. Paris.

Choksy, J.K. 1990a. "Gesture in Ancient Iran and Central Asia I: The Raised Hand", in Iranica varia. Papers in Honor of Professor Ehsan Yarshater (Acta Iranica 30). Leiden, 30-37.

Choksy, J.K. 1990b. "Gesture in Ancient Iran and Central Asia II: Proskynesis and the Bent Forefinger", BAI n.s. 4, 201-207.

Clark, C.A. 2009. “To Kneel or Not to Kneel: Gendered Nonverbal Behavior in Greek Ritual”, in S. Calef, R.A. Simkins (eds.), Women, Gender, and Religion (Journal of Religion and Society Suppl. 5). Omaha, 6-20.

Couch, H.N. 1931. "Proskynesis and Abasement in Aeschylus", CP 26, 316-318.

Cranmer-Byng, J.L. 2000. An Embassy to China: Lord Macartney's Journal, 1793-1794. London - New York.

Delatte, A. 1951. "Le baiser, l'agenouillement et le prosternement de l'adoration ( $\pi \rho \circ \sigma k u ́ v \eta \sigma ı)$ chez les Grecs", Bulletin de la Classe des lettres et des sciences morales et politiques de l'Academie royale de Belgique, sér. 5, 37, 423-450.

Eppihimer, M. 2013. “Representing Ashur: The Old Assyrian Rulers' Seals and Their Ur III Prototype", JNES 72, 35-49.

Faraguna, M. 2003. “Alexander and the Greeks”, in J. Roisman (ed.), Brill's Companion to Alexander the Great. Leiden, 99-130.

Fredricksmeyer, E. 2000. "Alexander the Great and the Kingship of Asia", in A.B. Bosworth, E.J. Baynham (eds.), Alexander the Great in Fact and Fiction. Oxford, 136-166.

Frye, R.N. 1972. "Gestures of Deference to Royalty in Ancient Iran”, IrAnt 9, 102-107.

Goldman, B. 1990. "Some Assyrian Gestures”, BAI n.s. 4, 41-49.

Gould, J. 1973. "Hiketeia”, JHS 93, 74-103. 
Gow, A.S.F. 1928. "Notes on the Persae of Aeschylus", JHS 48, 133-158.

Hall, E. 1989. Inventing the Barbarian: Greek Self-Definition through Tragedy (Oxford Classical Monographs). Oxford.

Hamilton, J.R. 1969. Plutarch: Alexander. Oxford.

Holden, H.A. 1887. The Cyropaedeia of Xenophon: Books III, IV, V, with Notes. Cambridge.

Horst, J. 1932. Proskynein: Zur Anbetung im Urchristentum nach ihrer religionsgeschichtlichen Eigenart. Gütersloh.

How, W.W., Wells, J. 1912. A Commentary on Herodotus, Vol. 1. Oxford.

Junge, P.J. 1940. "Hazarapatiš: Zur Stellung des Chiliarchen der kgl. Leibgarde im Achämenidenstaat”, Klio 33, 13-38.

Kaptan, D. 2002. The Daskyleion Bullae: Seal Images from the Western Achaemenid Empire (Achaemenid History 12), 2 vols. Leiden.

Kuhrt, A. 2007. The Persian Empire: A Corpus of Sources from the Achaemenid Period, London.

Lanfranchi, G., Roaf, M., Rollinger, R. (eds.) 2003. Continuity of Empire (?): Assyria, Media, Persia. Proceedings of the International Meeting in Padua, 26th-28th April 2001 (History of the Ancient Near East Monographs 5). Padua.

Lenfant, D. 2009. Les Histoires perses de Dinon et d'Héraclide (Persika 13). Paris.

Lincoln, B. 2007. Religion, Empire, and Torture: The Case of Achaemenian Persia, with a Postscript on Abu Ghraib. Chicago.

Llewellyn-Jones, L. 2013. King and Court in Ancient Persia 559 to 331 BCE (Debates and Documents in Ancient History). Edinburgh.

Llewellyn-Jones, L. 2015. “'That My Body Is Strong': The Physique and Appearance of Achaemenid Monarchy", in D. Boschung, A. Shapiro, F. Wascheck (eds.), Bodies in Transition: Dissolving the Boundaries of Embodied Knowledge (Morphomata 23). Paderborn, 211-248.

Lloyd, A.B. 1975-1976. Herodotus, Book II: Introduction, Commentary 1-98 (EPRO 43), 2 vols. Leiden.

Macleod, M.D. 1967. Lucian, vol. viii (Loeb Classical Library 432). London - Cambridge, Mass.

Marinatos, N. 2007. "Proskynesis and Minoan Theocracy", in F. Lang, C.

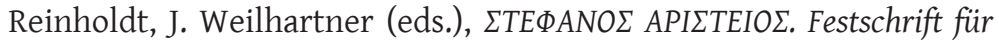
Stephan Hiller zum 65. Geburtstag. Vienna, 179-185.

Marti, B.M. 1936. "Proskynesis and Adorare", Language 12, 272-282.

Matarese, C. 2013. "Proskynēsis and the Gesture of the Kiss at Alexander's Court: The Creation of a New Élite", Palamedes 8, 75-85.

Matarese, C. 2014. "Sending a Kiss to the King: The Achaemenid Proskynēsis between Explanations and Misunderstandings", AncW 45, 122-145. 
Mitropoulou, E. 1975. Kneeling Worshippers in Greek and Oriental Literature and Art. Athens.

Moorey, P.R.S. 1988. "Religion and the Rulers", in CAH': Plates to Volume 4, 45-50. Muccioli, F. 2016. "Classical Sources and Proskynesis: History of a Misunderstanding”, in C. Bearzot, F. Landucci (eds.), Alexander's Legacy. Atti del Convegno, Università Cattolica del Sacro Cuore, Milano 2015. Rome, 41-59.

Musti, D. 2003. "Posidonio e l'etimologia di Proskynesis", in EPKO . Studi in Onore di Franco Sartori. Padua, 159-170.

Olbrycht, M.J. 2014. “'An Admirer of Persian Ways': Alexander the Great's Reforms in Parthia-Hyrcania and the Iranian Heritage", in T. Daryaee, A. Mousavi, K. Rezakhani (eds.), Excavating an Empire: Achaemenid Persia in Longue Durée. Costa Mesa, 37-62.

Osada, T. 2012. "Die Entmythologisierung des Alexandermosaiks anhand der Darstellung des Dareios", in C. Reinholdt, W. Wohlmayr (eds.), Akten des 13. Österreichischer Archäologentages: Klassische und Frühägäische Archäologie, Paris-Lodron-Universität Salzburg, vom 25. bis 27. Februar 2010. Vienna, 145-152.

Panaino, A. 2000. "The Mesopotamian Heritage of Achaemenian Kingship”, in S. Aro, R.M. Whiting (eds.), The Heirs of Assyria. Proceedings of the Opening Symposium of the Assyrian and Babylonian Intellectual Heritage Project. Held in Tvärminne, Finland, October 8-11, 1998. Helsinki, 35-49.

Pease, A.S. 1911. “The Omen of Sneezing”, CP 6, 429-443.

Powell, J.E. 2004. A Lexicon to Herodotus, 2nd ed. Hildescheim.

Pulleyn, S. 1997. Prayer in Greek Religion (Oxford Classical Monographs). Oxford.

Richards, G.C. 1934. "Proskynesis", CR 48, 168-170.

Root, M.C. 1979. The King and Kingship in Achaemenid Art: Essays on the Creation of an Iconography of Empire (Acta Iranica 19). Leiden.

Sachsen-Meiningen, F. von. 1960. "Proskynesis in Iran”, in F. Altheim (ed.), Geschichte der Hunnen, Vol. II: Die Hephthaliten in Iran. Berlin, 125-166.

Sancisi-Weerdenburg, H. 1988. "Was There Ever a Median Empire?", in A. Kuhrt, H. Sancisi-Weerdenburg (eds.), Method and Theory (Achaemenid History 3). Leiden, 197-212.

Schmidt, M. 1982. “Asia und Apate”, in M.L. Gualandi, L. Massei, S. Settis (eds.), 'A $\alpha$ $\rho \chi \alpha i ́$. Nuove ricerche e studi sulla Magna Grecia e la Sicilia antica in onore di Paolo Enrico Arias (Biblioteca di Studi Antichi 35), Vol. 2. Pisa, 505-520.

Scott, J.A. 1922. "The Gesture of Proskynesis", CJ 17, 403-404.

Spawforth, A.J.S. 2007. "The Court of Alexander the Great between Europe and Asia", in A.J.S. Spawforth (ed.), The Court and Court Society in Ancient Monarchies. Cambridge, 82-120. 
Stevenson, R.B. 1997. Persica: Greek Writing about Persia in the Fourth Century BC (Scottish Classical Studies 5). Edinburgh.

Stoneman, R. 2015. Xerxes: A Persian Life. New Haven - London.

Stronach, D. 2002. "Icons of Dominion: Review Scenes at Til Barsip and Persepolis", IrAnt 37, 373-402.

Taylor, L.R. 1927. “The 'Proskynesis' and the Hellenistic Ruler Cult”, JHS 47, 5362.

Taylor, L.R. 1931. The Divinity of the Roman Emperor. Middletown, Conn.

Tilia, A.B. 1972. Studies and Restorations at Persepolis and Other Sites of Fārs (IsMEO Reports and Memoirs 16). Rome.

Trendall, A.D. 1989. Red Figure Vases of South Italy and Sicily: A Handbook (World of Art). London.

Trendall, A.D., Cambitoglou, A. 1982. The Red-Figured Vases of Apulia (Oxford Monographs on Classical Archaeology), Vol. II: Late Apulian. Oxford.

Tuplin, C.J. 2017. "The Great King, His God(s) and Intimations of Divinity: The Achaemenid Hinterland of Ruler Cult?", AHB 31, 92-111.

Ussher, R.G. 1993. The Character of Theophrastus, 2nd ed. London.

van der Horst, P.W. 2013. "The Omen of Sneezing”, AncSoc 43, 213-221.

van Straten, F.T. 1974. "Did the Greeks Kneel before Their Gods?”, BABesch 49, 159-189.

van Straten, F.T. 1981. "Gifts for the Gods", in H.S. Versnel (ed.), Faith, Hope and Worship: Aspects of Religious Mentality in the Ancient World. Leiden, 65-151.

von Graeve, V. 1970. Der Alexandersarkophag und seine Werkstatt (Istanbuler Forschungen 28). Berlin.

Wiesehöfer, J. 2001. "Proskynesis”, Der Neue Pauly 10, 443-444.

Wiesehöfer, J. 2003. “'Denn ihr huldigt nicht einem Menschen als eurem Herrscher, sondern nur den Göttern': Bemerkungen zur Proskynese in Iran", in C. Cereti, M. Maggi, E. Provasi (eds.), Religious Themes and Texts of Pre-Islamic Iran and Central Asia. Studies in Honour of Professor Gherardo Gnoli on the Occasion of His 65th Birthday on 6th December 2002. Wiesbaden, 447-452. 


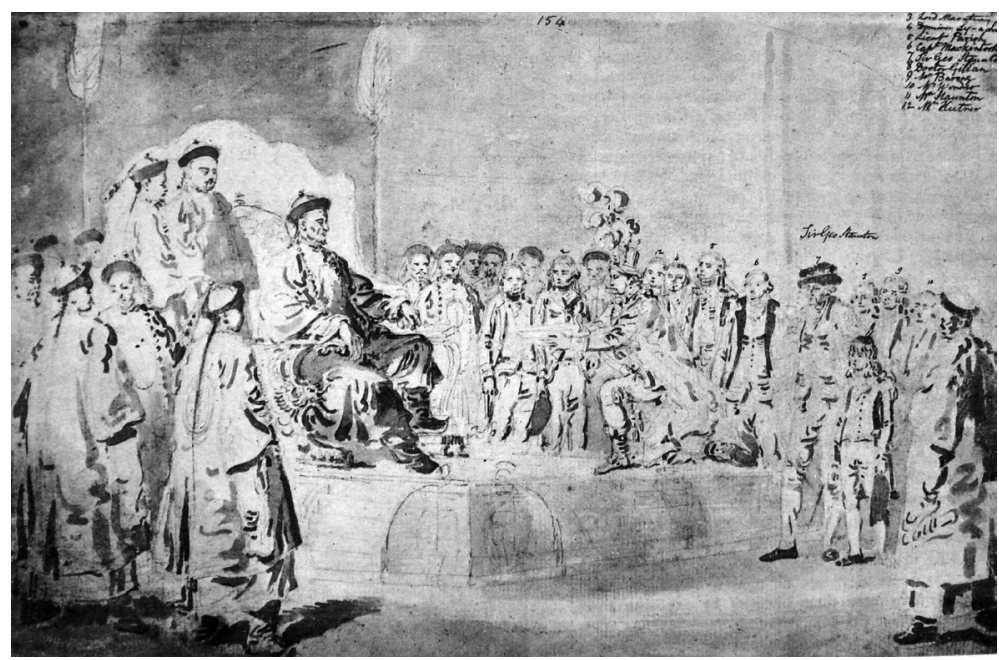

Fig. 1. Lord Macartney's first meeting with the Qianlong Emperor, 1793 (public domain).
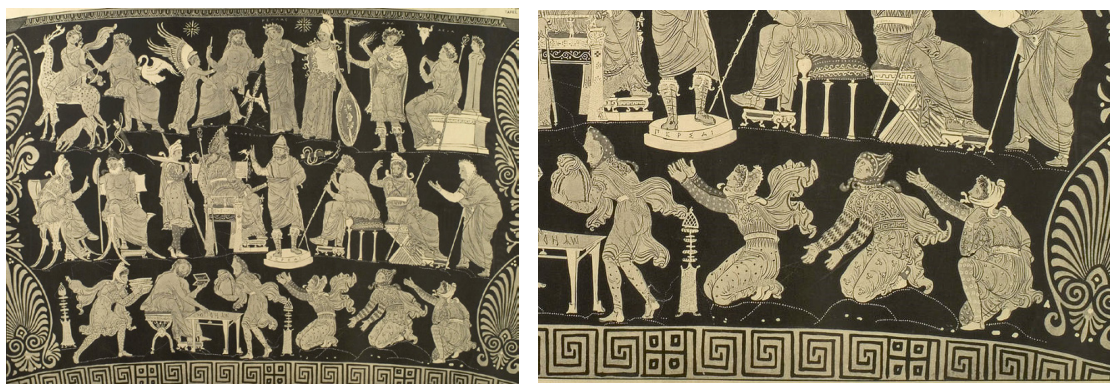

Fig. 2a-b. The "Darius Vase" (Naples 3253) (Heidelberg University Library, http://digi.ub.uni-heidelberg.de/diglit/furtwaengler1904bd2/0032 - CC-BYSA 3.0, adapted). 


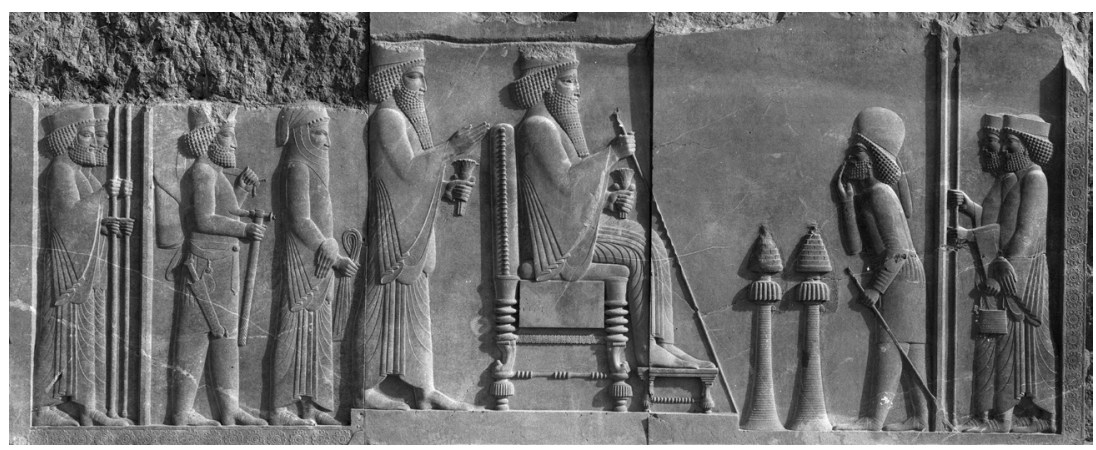

Fig. 3. Audience scene in the Treasury relief, Persepolis (Courtesy of the Oriental Institute of the University of Chicago).

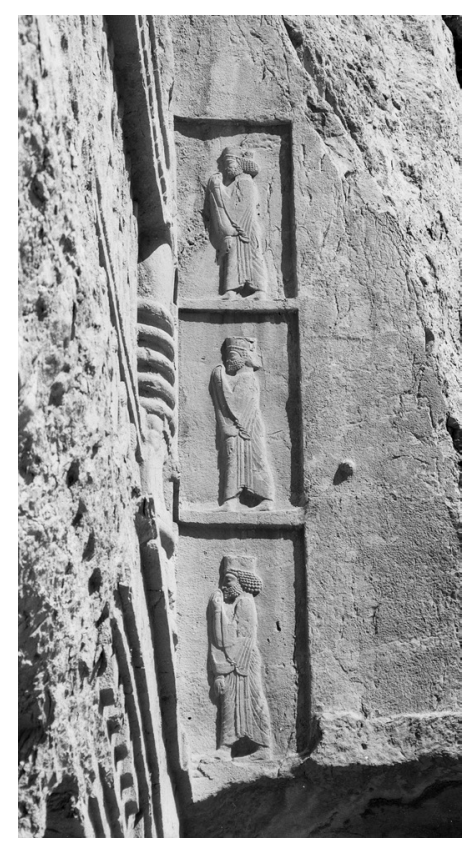

Fig. 4. The "mourners" of the tomb of Darius II, Naqsh-i-Rustam (Courtesy of the Oriental Institute of the University of (hicago). 


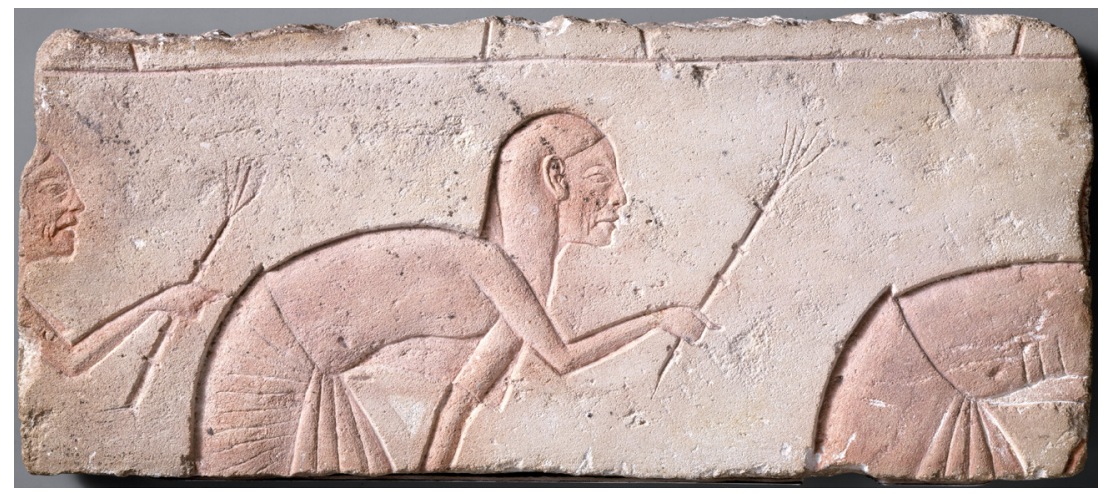

Fig. 5. Relief of bowing attendants from Amarna (The Metropolitan Museum, 1985.328.9) (public domain).

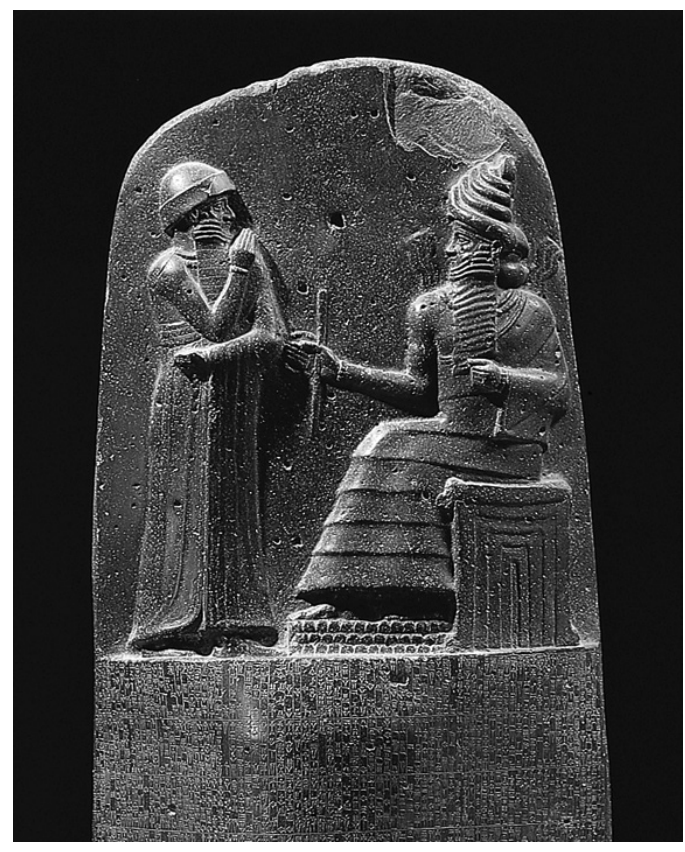

Fig. 6. The upper part of the stela of Hammurabi's code of laws (public domain). 


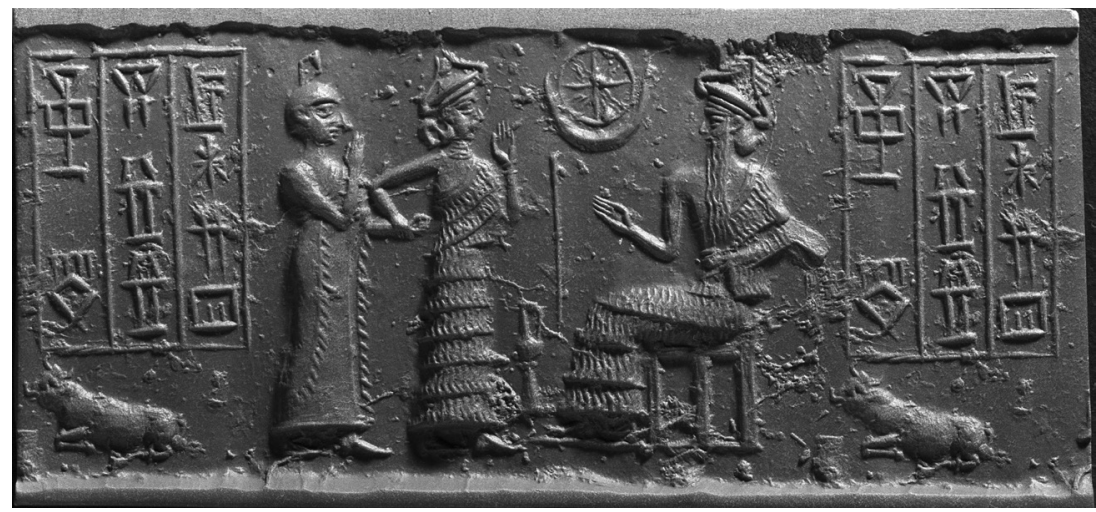

Fig. 7. Morgan seal no. 277 (Courtesy of the Morgan Library and Museum).

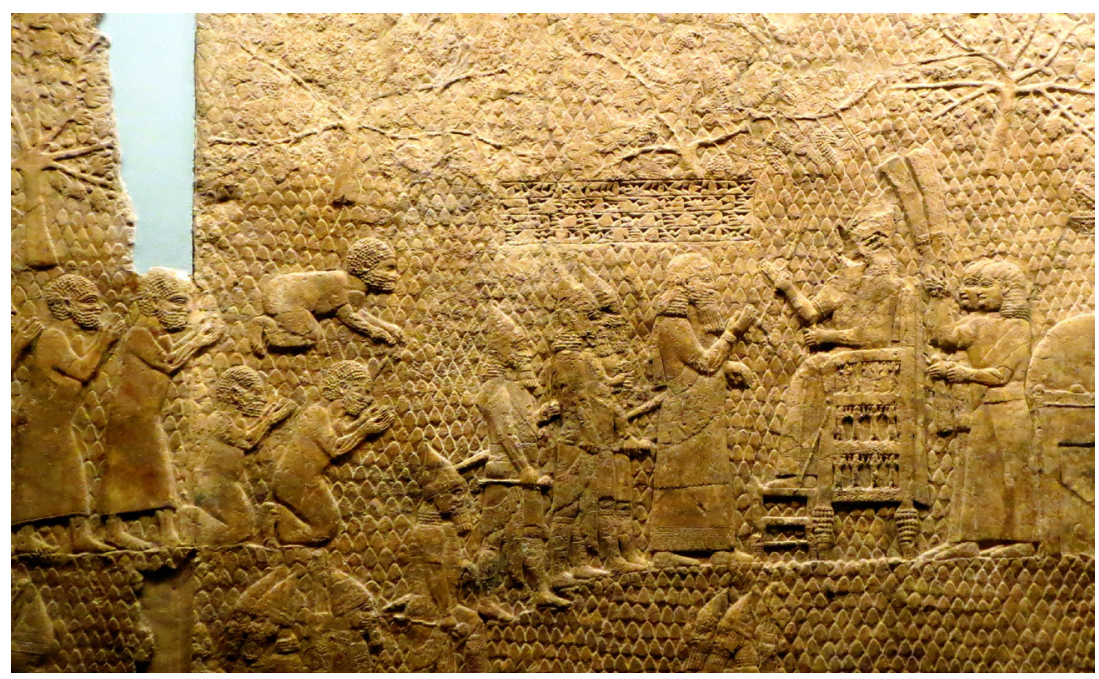

Fig. 8. The relief of the fall of Lachish (Photo by the author). 
